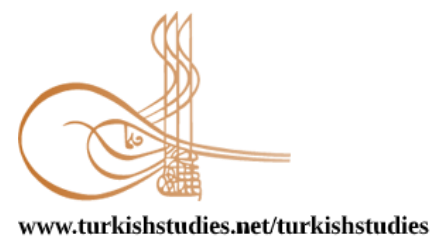

Turkish Studies

\title{
Bilgisayarlı Tomografik Tarama Teknolojisi İle Tarihi Bir Çalgı İçin Morfolojik İnceleme: İstanbul Kemençesi*
}

\author{
Computerized Tomographical Scanning Technology and Morphological Analysis for a Musical \\ Instrument: Istanbul Kemençe
}

\author{
Murat Küçükebe ${ }^{* *}$
}

\begin{abstract}
In the past, instrument making was a profession that continued with knowledge transferred from master to apprentice as the traditional method deems appropriate. Today, the profession in question has gained an academic identity through the instrument making departments opened in our universities, along with the traditional method carried out in market conditions and has become a scientific and artistic practice and research area that attracts more and more attention abroad, as well. However, although there are many written documents about the history of Turkish music, there are very few written sources about the producers of the instruments used in performance, their working styles or the characteristics of the instruments produced. With a general evaluation, information on the subject is mostly obtained through the recordings and notes made by the producers of the few instruments that have survived until today. However, a second source that contributes to the formation of the aforementioned information is some scraps of information obtained from the memories of old musicians. It is known that due to the scarcity of instrument museums and quality inventory studies in our country, many historically important instruments succumbed to bad conditions and disappeared over time. It is seen that a serious morphological examination has not yet been made for the few instruments that have survived the bad conditions due to the fact that the 'method' problem has not been overcome. Taking into account the problem briefly summarized above, this study aims to present a proposal for a morphological examination method to the benefit of practitioners who want to make artistic works based on scientific foundations in the field of organology and applied organology. Together with the cross-sectional images to be obtained through the use of computerized tomographic scanning technology on a historically important classical kemençe, the aforementioned examination will contribute both to the above-mentioned issues and the instrument museum and inventory studies in our country. The study was found ethically appropriate by the Social and Human Sciences Research and Publication Ethics Committee of Dokuz Eylül University in line with the decision no.10 taken on 07.07.2021.
\end{abstract}

\footnotetext{
* Teşekkür: Araştırmaya konu olan kemençenin sahibi ve görüşme kişisi Mehmet Güntekin'e, diğer görüşme kişileri Fikret Karakaya, Ahmet Kadri Rizeli, Murat Yerden, Mahmut İnanç ve Orçun Güneşer'e, bilgisayarlı tomografi görüntüleme programının kullanımı ve bulguların yorumlanması aşamasındaki yardımları için Prof. Dr. Oğuz Dicle'ye, teknik konulardaki destek ve önerileri için Metin Akkeçeli'ye ve tomografik taramanın gerçekleştirilmesi aşamasındaki desteği için Kadir Bozdoğan'a içten teşekkürlerimi sunarım.

${ }^{* * *}$ Dr. Öğr. Üyesi, Dokuz Eylül Üniversitesi, Devlet Konservatuvarı, Müzik Bölümü.

Asst. Prof. Dr., Dokuz Eylül University, State Conservatory, Music Department.

ORCID0000-0002-5741-6571
}

murat.kucukebe@deu.edu.tr

Cite as/ Atıf: Küçükebe, M. (2021). Bilgisayarlı tomografik tarama teknolojisi ile tarihi bir çalgı için morfolojik inceleme: İstanbul kemençesi. Turkish Studies, 16(5), 1553-1581. https://dx.doi.org/10.7827/TurkishStudies.52174

Received/Geliş: 28 July/Temmuz 2021

Accepted/Kabul: 25 September/Eylül 2021

Checked by plagiarism software

Published/Yayın: 30 September/Eylül 2021

CC BY-NC 4.0 
Structured Abstract: In the past, instrument making was a profession that continued with knowledge transferred from master to apprentice as the traditional method deems appropriate. Today, the profession in question has gained an academic identity through the instrument making departments opened in our universities, along with the traditional method carried out in market conditions and has become a scientific and artistic practice and research area that attracts more and more attention abroad, as well. However, although there are many written documents about the history of Turkish music, there are very few written sources about the producers of the instruments used in performance, their working styles or the characteristics of the instruments produced. With a general evaluation, information on the subject is mostly obtained through the recordings and notes made by the producers of the few instruments that have survived until today. However, a second source that contributes to the formation of the aforementioned information is some scraps of information obtained from the memories of old musicians. It is known that due to the scarcity of instrument museums and quality inventory studies in our country, many historically important instruments succumbed to bad conditions and disappeared over time. It is seen that a serious morphological examination has not yet been made for the few instruments that have survived the bad conditions due to the fact that the 'method' problem has not been overcome. Taking into account the problem briefly summarized above, this study aims to present a proposal for a morphological examination method to the benefit of practitioners who want to make artistic works based on scientific foundations in the field of organology and applied organology. Together with the cross-sectional images to be obtained through the use of computerized tomographic scanning technology on a historically important classical kemençe, the aforementioned examination will contribute both to the above-mentioned issues and the instrument museum and inventory studies in our country.

With a simple definition, the working principle of the computer tomography device, which can be said to be an advanced X-ray device, is to obtain cross-sectional images of the examination region by scanning the examination area at a certain speed, through a a continuously rotating part called gantry via subjecting the obtained digital data to high mathematical analysis with computer programs. At this point, whether it is a living or inanimate object, the values of the X-ray beams absorbed according to the physical properties of the scan constitute the basic data reference needed for the mathematical analysis and processing procedure performed by the computer (Ulu, 2008: 32-22). In terms of the basic principle, the most important difference between radiological examination technology, which is another technology for obtaining images through X-rays, and computerized tomographic scanning technology, offers an application that makes it possible to obtain cross-sectional images instead of overlapping images that appear in radiological examination results. Apart from this, the fact that the results can be reached 'fast' and 'without intervention' stands out as another important advantage that makes this technology important.

Based on this difference and advantage, the use of CT (computerized tomography) technology, which has been used in the medical field since the seventies, has become diversified, from historical artifacts and archaeological finds to instrument examinations. Notman-Tashijan (1986), Marx-Auria (1988) and Harwood-Nash's (1979) studies dealing with the study of ancient Egyptian mummies, Falke's (1987) study which aims to examine an ancient Egyptian cat, and an ancient English sword and Mazansky's work (1993) are amongst the prominent examples that makes this diversity visible in the literature.

As a result, paleoradiology (Hofman, 2002-Cavka, 2013), which is now accepted as the name of a special field related to the study of anthropological and paleontological materials, has come a long way since it overlapped with the morphological study needed in studies on the field of organology, which is at the center of this article. Together with many publications on the examination of instruments with high historical and economic value, especially of Italian origin, has come to the present day by creating an ever-increasing publication accumulation. At this point, publications by Sir-Waddle duo in various dates (1989, 1997, 1999, 2009, 2014 a,b) and another publication by Gattoni-Melgara (1997) are the first studies aiming to reveal detailed and qualified research results through the use of the aforementioned technology.

Based on the examination results of the publications in the literature, cross-sectional images created by virtual slicing, the surface shapes and interior volume properties of the instruments, the wall thickness and density values of the material used in the construction of the instrument, the restoration areas and some usage forms have become clear in order to obtain information about the procedures performed (Küçükebe, 2016: 895-918). A study on our traditional instruments has not yet been presented within the academic literature of our country on the subject. With a short review it is seen that examining an instrument is limited to the general characteristics of the parts related to fulfilling its basic function as a musical 
instrument which is a common feature that is dominant in all studies that have "structural feature" in the title. Different from this, the article aims to approach the subject directly from a morphological point of view.

In the article requiring a multidisciplinary method in data collection; the kemençe is presented to an environment that stands out in terms of representing the tradition in order to be evaluated in terms of its stylistic features, and it is discussed in detail through the use of computer tomographic scanning technology.

Due to the pandemic conditions, the interviews were held online between the dates 19-23/07/2021 and the interviewees were asked to make an evaluation on the production features attributed to Baron Baronak who is known as the possible producer of the kemençe.

However, the study also contains the application of a specific method in connection with computer scanning technology which first emerged with its use on the human body in the medical world, but later became a special field of study for examining anthropological or paleontological materials in the context of paleoradiology, to the field of organology.

Tomographic scanning process was performed on 23. 06. 2021 by the radiology unit officers working in Istanbul, Medipol Mega University Hospital, under the management and control of responsible technician Kadir Bozdoğan, with a Siemens brand and Somatom Force model computerized tomography device with 1152 detector number, acquisition values 0.5 . mm., section thickness, 512 by 512 matrix, in the axial plane. Thanks to the reconstruction of the section images by the device, section images of the instrument belonging to other planes, including sagittal and coronal were obtained.

During the use of the Osirix Dicom Viewer program and the interpretation of the findings, support was received from Prof. Dr. Oğuz Dicle, Dokuz Eylul University Faculty of Medicine, Department of Internal Medicine, Department of Radiology.

Photographs of the instrument were taken in certain plans, basic information about the construction material and basic construction measurements were presented through standard tables, and information on the traces of restoration that had been carried out before were recorded.

Interviews have shown that people establish a relationship between the stylistic features of the instrument and its producer. Interviewees interpreted the instrument by taking particular parts into account in order to refer to its stylistic features. At this point, the general shape of the tail block and the gouges on the block, the general shape and depth of the back gouge, the body shape in the sagittal and coronal planes, the shape of the sound holes, the application of the mihrap, the thickness and the structure of the head should be determined in relation to the stylistic elements in question. These are the main regions that are carefully observed and evaluated by the interviewees. Interviewees talk about the existence of a consistent stylistic feature in Baron-made kemençes, which they see as the producer of the instrument that is the subject of the research. However, it will be possible to accept these features of the parts in question within the framework of the 'stylistic feature' of the aforementioned master, based on a qualified determination, as a result of compiling the information to be made on a large number of sample instruments that are stated to belong to the master or confirmed by important sources.

With this study, the first experiment on the use of computerized tomographic scanning technology, which has been proven to be effective for many European instruments, has been carried out for one of the important instruments of our musical tradition. Examining other historically important old instruments in our country in a similar way and recording their information will serve to create a comprehensive inventory and make a very important contribution to the formation of the "historical reference" needed in order to talk about the "tradition" of instrument making in our country. Moreover, these studies will provide information about the cultural and aesthetic universe in which the instrument is located, as well as information about morphological features. From this perspective, our traditional instruments are in a position to deserve to be handled 'directly' even with their only formal features. Through the increase of similar studies and the sharing of the results of qualified studies, cultural awareness will be increased, the power of Turkish individuals to compete with their colleagues operating in the same field abroad will be reinforced and the new generation engaged in the art of instrument making, interested in research and self-development in this field will have the concrete examination material they need.

Keywords: Organology, musical instrument making, Istanbul kemençe, computerized tomography, morphological anlaysis, Baron Baronak 
Öz: Çalg1 yapımcılı̆̆ geçmişte ustadan çırağa geçecek biçimde, geleneksel yöntemin uygun gördüğü şekilde aktarılan bilgilerle devam eden bir meslek dalıydı. Günümüzde ise söz konusu meslek, piyasa koşullarında sürdürülen geleneksel yöntemle birlikte, üniversitelerimizde açılan çalgı yapım bölümleri aracılığıyla akademik bir kimlik de kazanmış ve yurt dışında da olduğu gibi giderek daha fazla ilgi gören, bilimsel ve sanatsal bir uygulama ve araştırma alanı halini almış durumdadır. Ne var ki Türk müziği tarihi hakkında birçok yazılı belge bulunmasına karşılık, halen icrada kullanılan çalgıların yapımcılarını, çalışma biçimleri ya da üretilen çalgıların özelliklerini konu alan oldukça az sayıda yazılı kaynak bulunmaktadır. Genel bir değerlendirmeyle konuyla ilgili bilgiye çoğu zaman, günümüze kadar sağlam şekilde kalabilen az sayıdaki çalgının içine, yapımcılarınca düşülen kayıtlar ve notlar aracılığıyla ulaşılmaktadır. Bununla birlikte söz konusu bilginin oluşumuna katkı sağlayan ikinci bir kaynak da eski müzik insanlarının anılarından elde edilen bazı bilgi kırıntılarıdır. Ülkemizde bulunan çalgı müzeleri ve nitelikli envanter oluşturma çalışmalarının azlığına da bağlı olarak tarihi öneme sahip çok sayıda çalgının zamanla kötü koşullara yenik düşerek ortadan kaybolduğu bilinmektedir. Kötü koşulları aşarak günümüze kadar sağlam şekilde kalabilmiş az sayıda çalgı için ise, morfolojik açıdan ciddi bir incelemenin, 'yöntem' sorununun aşılamamış olması sebebiyle, halen yapılamamış olduğu görülmektedir. Bu makale, yukarıda kısaca özetlenen sorunu da dikkate alarak, organoloji ve uygulamalı organoloji alanında bilimsel temellere dayanan sanatsal çalışmalar yapmak isteyen uygulayıcıları, makale aracılığı ile ele alınan konuya ilgi duyacak araştırmacıların yararını ve bir morfolojik inceleme yöntemi önerisi ortaya koymayı amaçlamaktadır. Tarihi öneme sahip bir klasik kemençe üzerinde bilgisayarlı tomografik tarama teknolojisinin kullanımı yoluyla ulaşılacak kesit görüntüler ile birlikte söz konusu inceleme, gerek yukarıda sözü edilen hususlar gerekse ülkemiz çalgı müzeciliği ve envanter oluşturma çalışmaları açısından katkı sağlayıcı olacaktır. Çalışma, Dokuz Eylül Üniversitesi, Sosyal ve Beşerî Bilimler Araştırma ve Yayın Etik Kurulu tarafından, 07.07.2021 tarihinde alınan, 10 sayılı karar doğrultusunda, etik açıdan uygun bulunmuştur.

Anahtar Kelimeler: Çalgıbilim, çalgı yapım, İstanbul kemençesi, bilgisayarlı tomografi, morfolojik inceleme, Baron Baronak

\section{Giriș}

Basit bir tanımlamayla temel olarak gelişmiş bir X 1şını cihazı olduğu söylenebilecek bilgisayarlı tomografi cihazının çalışma prensibi, belirli bir hızda, sürekli şekilde dönen gantri adı verilen bölüm aracılığıyla, inceleme bölgesi üzerinde tarama yapmaya, elde edilen dijital verinin bilgisayar programları ile yüksek matematik çözümlemelere tabi tutulması ve işlenmesi sonucunda, inceleme bölgesine ait kesit görüntüler elde etmeye dayanmaktadır. Bu noktada canlı ya da cansız bir nesne olsun, taranın fiziksel özelliklerine göre emilime uğrayan X ışını demetlerine ait değerler, bilgisayar tarafindan gerçekleştirilen söz konusu matematiksel çözümleme ve işleme prosedürü için ihtiyaç duyulan temel veri referansını oluşturmaktadır (Ulu, 2008: 32-36). Temel prensip açısından bakıldığında, $X$ ışınları aracılığıyla görüntü elde etmeye yönelik bir başka teknoloji olan radyolojik inceleme teknolojisi ile bilgisayarlı tomografik tarama teknolojisi arasındaki en önemli fark, radyolojik inceleme sonuçlarında ortaya çıan üst üste binen görüntüler yerine, kesit görüntüler elde etmeyi olanaklı hale getiren bir uygulama sunuyor olmasıdır. Bunun dışında sonuçlara 'hızlı' ve 'müdahalesiz' biçimde ulaş1labiliyor olması da söz konusu teknolojiyi önemli kılan bir başka önemli avantaj olarak öne çıkmaktadır.

$\mathrm{Bu}$ fark ve avantajdan hareketle, yetmişli yıllardan itibaren tıp alanında kullanılan BT (bilgisayarlı tomografi) teknolojisinin, sonraları tarihi eser ve arkeolojik buluntulardan, çalg1 incelemelerine kadar değişim gösterecek şekilde, kullanım alanı çeşitlilik kazanmıştır. Eski Mısır mumyalarının incelenmesi ile ilgili olan Notman-Tashijan (1986), Marx-Auria (1988) ve HarwoodNash'ın çalışmaları (1979), eski bir Mısır kedisini incelemeyi amaçlayan Falke'nin çalışması (1987) ve eski bir İngiliz kılıcını konu alan Mazansky'nin çalışması (1993), söz konusu çeşitliliğe literatür üzerinde görünürlük kazandıran belirgin örnekler arasında yerini almıştır.

Sonuç olarak artık antropolojik ve paleontolojik materyalleri incelemeye ilişkin özel bir alanın adı olarak kabul görmüş bulunan paleoradyoloji (Hofman, 2002-Cavka, 2013), bu makalenin 
merkezine yerleşen çalgıbilim alanına ilişkin çalışmalarda ihtiyaç duyulan morfolojik inceleme konusu ile örtüştüğü tarihten itibaren uzun bir yol kat ederek, özellikle İtalya kökenli olan tarihi ve ekonomik değeri yüksek çalgıları incelemeyi konu alan pek çok yayın ile birlikte, giderek artan bir yayın birikimi oluşturarak günümüze kadar gelmiş durumdadır. Bu noktada Sir-Waddle ikilisi tarafindan çeşitli tarihlerde ortaya konan yayınlar (1989, 1997, 1999, 2009, 2014 a-b) ile GattoniMelgara'ya ait bir başka yayın (1997), adı geçen teknolojinin kullanımı yoluyla ayrıntılı ve nitelikli inceleme sonuçları ortaya koymayı hedefleyen ilk çalışmalardır.

Literatürdeki yayınlara ait inceleme sonuçlarından hareketle çalgıbilim çalışmalarında, sanal dilimlemeler sayesinde oluşturulan kesit görüntüler ile çalgıların yüzey şekilleri ve iç hacim özellikleri, çalgının yapımında kullanılan malzemenin et kalınlığı ve yoğunluk değerleri, restorasyon bölgeleri ve yapılan işlemler hakkında bilgi elde etmeye yönelik olarak belirginlik kazanmış bazı kullanım biçimleri ile ayrıntılı karşılaştırma çalışmaları ortaya koyma hedeflerinin öne çıktığı anlaşılmaktadır (Küçükebe, 2016: 895-918). Konu ile ilgili ülkemiz akademik yazını dahilinde geleneksel çalgılarımızı konu alacak bir çalışma henüz ortaya konmamıştır. Yapılacak kısa bir tarama ile başlığında 'yapısal özellik' geçen ve bir çalgıyı incelemeyi konu edinen tüm çalışmalarda hâkim olan ortak bir özellik olarak anlatım, bir müzik aleti olarak temel işlevini yerine getirmekle ilgili bölümlerin genel düzen ve özelliğine ait bilgilerle sınırlı tutulmuş durumdadır. Bundan farklı şekilde bu makale, konuya doğrudan morfolojik (biçim bilimsel) açıdan yaklaşmayı amaçlamaktadır.

\section{Yöntem}

Veri toplama aşaması çok disiplinli bir yapılanmayı gerektiren araştırmada, incelemeye konu olan kemençe, taşıdığı biçemsel özellikler bakımından değerlendirilmesi için, geleneği temsil etme açısından öne çıkan bir çevreye sunulmakla birlikte, bilgisayarlı tomografik tarama teknolojisinin kullanımı yolu ile morfolojik yönden ayrıntılı biçimde ele alınmıştır.

Pandemi koşulları nedeniyle görüşmeler, 19-23/07/2021 tarihleri arasında, çevrimiçi ortam ve telefon görüşmeleri üzerinden gerçekleştirilmiş ve kemençenin muhtemel yapımcısı olarak adı anılan Baron Baronak'a isnat edilen yapım özellikleri üzerinden görüşme kişilerinin bir değerlendirme yapması istenmiştir. Çalışma, Dokuz Eylül Üniversitesi, Sosyal ve Beşerî Bilimler Araştırma ve Yayın Etik Kurulu tarafindan, 07.07.2021 tarihinde alınan, 10 sayılı karar doğrultusunda, etik açıdan uygun bulunmuştur.

Araştırma, öncelikle tıp dünyasında, insan bedeni üzerindeki kullanımıyla ortaya çıkan, ancak daha sonra antropolojik ya da paleontolojik materyalleri incelemeye ilişkin özel bir çalışma alanı haline gelen paleoradyoloji bağlamında, bilgisayarlı tarama teknolojisinin ve söz konusu teknoloji ile bağlantılı şekilde çalgı bilim alanına da uygulanır hale gelen belirli bir inceleme yönteminin kullanımını içermiştir.

Tomografik tarama işlemi 23. 06. 2021 tarihinde, İstanbul, Medipol Mega Üniversite Hastahanesi'nde çalışan radyoloji birimi görevlilerince, sorumlu tekniker Kadir Bozdoğan yönetimi ve kontrolünde, Siemens marka ve Somatom Force model, 1152 dedektör sayısına sahip bilgisayarlı tomografi cihazı ile, çekim değerleri $0.5 \mathrm{~mm}$. kesit kalınlığı, 512'ye 512 matrix olmak üzere, aksiyal axial planda gerçekleştirilmiştir. Kesit görüntülerin cihaz tarafindan geriçatılması reconstruction sayesinde çalgının sajital sagittal ve koronal coronal olmak üzere diğer planlara ait olan kesit görüntüleri elde edilmiştir. 


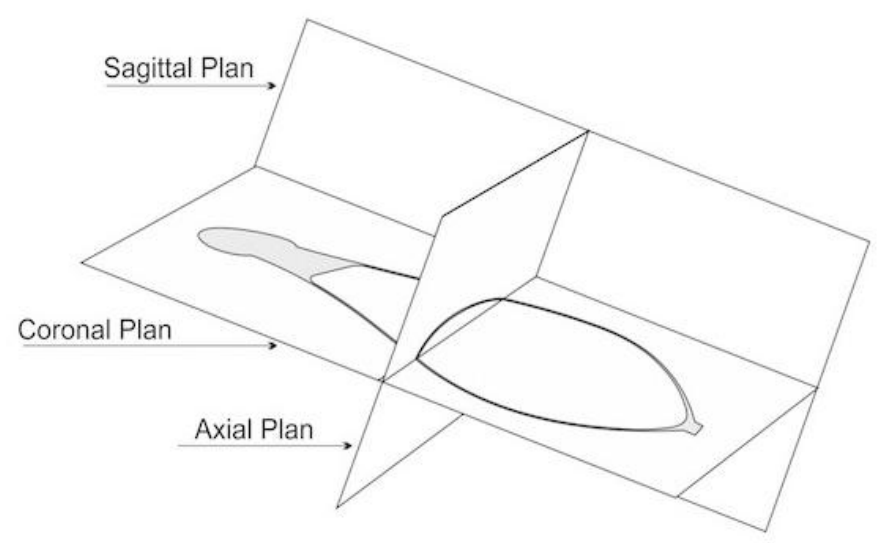

Şekil 1: Sagittal, Coronal ve Axial Planların Gösterimi

DICOM formatında görüntüleme yapan Osirix Dicom Viewer isimli programının kullanımı ve bulguların yorumlanması aşamasında, Dokuz Eylül Üniversitesi Tıp Fakültesi, Dahili Tıp Bilimleri Bölümü, Radyoloji Anabilim Dalı Öğretim Üyesi Prof. Dr. Oğuz Dicle'den destek alınmıştır.

Çalgının belirli planlarda olmak üzere fotoğrafları çekilmiş, yapım malzemesine ilişkin temel bilgi ile temel yapım ölçüleri, standart tablolar aracılığı ile sunulmuş, daha önce gerçekleştirilmiş olan restorasyon izlerine ilişkin bilgiler kayıt altına alınmıştır.

\section{Kısa Tarihi, Kültürel ve Kimliksel Yönü ile Kemençe}

Bugün çalg1 yapım sanatı açısından oldukça önemli sayılabilecek örneklerinin ülkemizde bulunduğu bilinen 'kemençenin', tarihi ile ilgili çalışmalardan elde edilen veriler, çalgının Bizans aracılığıyla İstanbul'dan Girit'e ulaştığını daha sonra buradaki halkın göçüyle İstanbul'a geri döndüğünü göstermektedir (Çolakoğu, 2008: 91-92). Çolakoğlu, Girit'te lyra olarak bilinen çalgının, 'kaba saz' gruplarından 'ince saz' takımlarına geçiş sürecini, İstanbul müziği ve kültür dairesi içerisinde kazandığı icra ve kimliksel yapı açısından uğradığı değişimle birlikte ele alarak ayrıntılı bir çalışma ortaya koymuştur (2008).

Çolakoğlu'nun sunduğu bilgi 1şığında, çalgı ile ilgili bazı bilgilerin yer aldığı en eski kaynakların, Ahmedoğlu Şükrullah'a ait 15. yy.'daki Risale min ilm'l-Edvar ile 1749 tarihli Hızır Ağa'ya ait Tefhim ül makamat fi tevlid en nagamat adlı yazma eserler olduğu görülmektedir. Hızır Ağa'ya ait kaynakta keman-1 kıpti olarak isimlendirilen, tek tel ve burgusu ile bu günkü durumundan farklı şekilde 'd' biçimli ses delikleri olmayan çalgının (Çolakoğlu, 2008: 93), kemençenin erken örneklerden biri olduğu düşünülmektedir. Yazar, çalg1 için 'keman' adının kullanılmış olmasını, Osmanlıca'da bu terimin bütün yaylı çalgıları niteleyecek biçimde kullanılmış olması ile ilişkilendirmektedir (Çolakoğlu, 2008: 93). Çolakoğlu aynı özelliklere sahip bir başka örneğin, divan şairi Enderuni Fazıl'a ait Hubanname ve Zenanname adlı eserin içinde, kır eğlencesini tasvir eden bir resimde de bulunduğunu belirtmektedir (2008: 93).

Çeşitli görevlerle ülkeye gelen yabancı seyyahların seyahatnameleri, çalgıyla ilgili bilginin elde edildiği diğer kaynaklardır. Bu kaynaklardan birinde Porter, Rumların İstanbul'da dans edip şarkı söylerken lyra adlı çalgıyı kullandığını anlatmaktadır (Simopoulos'tan akt. Çolakoğlu, 2008: 57). Aksoy, kendisinden önceki örneklerden farklı biçimde, çalgının bugünkü adına yer veren Blainville'nin, Musikinin Genel Eleştirel ve Filolojik Tarihi isimli eserinde (1767), genel biçimde çalgının fiziksel ve kullanım özelliklerinden bahsederken, bu günkü durumuna göre daha büyük olduğu çıkarılabilecek bir kemençe resmini de açıklamalarının beraberinde verdiğinden söz etmektedir (2003: 309). Çalgılar üzerine çalışmış bir diğer seyyah olarak Laborde ile 18. yy.'in sonlarında İstanbul'u ziyaret eden Carsten Niebuhr tarafindan kaleme alınan bir başka 
seyahatnamede de yine şehirde yaşayan Rumlar tarafindan kullanılmakta olduğu söylenen ve lyra adı ile anılan çalgının, kullanım ve fiziksel özellikleri tarif edilmekte, söz konusu anlatımların Blainville'nin aktardıkları ile örtüştüğü görülmektedir (Çolakoğlu, 2008:95)

Çalgıların, içinde yer aldıkları müziğin teknik ihtiyaçları ve işitsel unsurları kadar o müziği icra eden, paylaşan, belirli ifade normları ile paylaşılmış duyguyu ve anlam kalıplarını aktarmaya da aracı yapan toplumun kültür özelliklerini de barındırdığı, etnomüzikoloji yazını içerisinde çeşitli örneklerle incelenmiş ve kabul görmüş durumdadır. Bu çerçeveden bakıldığında, kemençeyi geçmişte ve günümüzde kullanan çevre, çalgının sahip olduğu kültürel birikimin oluşumu açısından önem kazanır. Çalgının sahip olduğu kültürel birikim, onu kullanan ya da tanıyan tüm kesimlerce kendisine yüklenen, çevreye ve zamana göre değişebilen tüm anlam katmanlarının biriktirildiği alana karşılık gelmektedir. Bu alan, aynı zamanda çalgının toplumca tanımlanmasına katkı sağlayacak aidiyetle ilgili tüm özellikleri içeren bir yapı olduğu için, ona kısaca 'kimlik' diyebiliriz. Konu bu yönüyle ele alındığında, kemençenin kimliğinin oluşumuna etki eden faktörlerin izini sürmek için, onun bir müzikal gereç olarak kullanıldığı başlıca mekanları dikkate almak yararlı olacaktır. Literatüre bakıldığında söz konusu yaklaşımı benimseyen çalışmalarca İstanbul'un eski mesire alanları, meyhane ve kahvehanelerinin ele alındığı görülmektedir. $\mathrm{Bu}$ noktada köçek, tavşan ve çengilerin de yer aldığı gezici profesyonel çalgı takımları olarak tanımlanan, Ege adalarıyla karşıllklı yaşanan kültürel etkileşim ve göçün etkisinin yanında şehir halk müziği ihtiyacı ile birlikte ortaya çıkan 'kaba saz' (Aksoy, 2003: 110) takımları öne çıkmaktadır. Kemençenin, adı geçen saz takımlarının daimi bir üyesi olarak, lavta ile birlikte tavşan ve köçek havalarına eşlik ettiği aktarılmaktadır. Çalgının bu topluluklardan 'ince saz' takımına geçişi için ise Rum asıllı kemençeci Vasil [1805-1947] ve Tanburi Cemil Bey'in [1871-1916] yeni icra anlayışları ile birlikte ustalık ve kişisel fikirlerinin etkili olduğu kabul edilmiş durumdadır.

Oğlu tarafindan kaleme alınan, usta kemençeci Tanburi Cemil Bey'in hayatı, (1947) Vasil'in sözlerine aracılık etmekte ve O'nun, kemençenin ince saz takımına dahil olması gerektiği yönündeki görüşünü günümüze nakletmektedir. Yine süreci değerlendiren Kemal Niyazi Seyhun'un sözleri, Cüneyd Orhon tarafindan aktarılmakta (1985) ve söz konusu değişimin, kemençenin pes tarafinda bulunan ve sadece 'ahenk teli' olarak kullanılan telinin, yegâh sesine ayarlanarak, çalgının 'sınırlı icradan' çıkarılması ile gerçekleştiğini göstermektedir. Böylelikle kemençe, sadece köçekçe ve tavşanca gibi oyunlu repertuar yerine, daha geniş bir repertuar ile saray fasıl heyeti tarafindan da kullanılabilecek, icra kapasitesi daha yüksek bir çalgı haline gelmiştir. Kısaca aktarımı yapılan bu süreç, elbette fiziki yapı ve icra biçiminde ortaya çıkan yeniliklerle birlikte çalgının dahil olduğu çevre, toplum tarafından algılanış biçimi ve meşruiyeti açısından da önemli bir dönüşümün yaşanmış olduğuna işaret etmektedir. Bu nedenle lavta ile birlikte köçekçe ya da tavşanca gibi havalara eşlik etme amacıyla sınırlı bir repertuar için kullanılan kaba saz, daha geniş bir repertuar ile saray fasıl heyeti tarafından da kullanılabilecek bir ince saz haline gelirken, artık sedef, fildişi ve bağa gibi oldukça pahalı malzemelerin yüksek bir işçilik değeri ile kullanıldığı seçkin yapım örnekleri, sınıfsal referans açısından öncekine göre daha yüksek bir kesimin özel talepleri gözetilerek, farklı bir üretim mantığı ile şekillendirilecektir. Günümüze ulaşan ve Baron, İzmitli ve Vasil ustalarla ilişkilendirilen çalgılar işte bu dönemin ürünüdürler.

Söz konusu dönüşüm sürecinde, kemençenin yapısında değişim gerektiren bazı denemelerin de yapıldığı bilinmektedir. Vasil ve Tanburi Cemil Bey’in çalgıya dördüncü bir tel ekleyerek icra etmeyi denemeleri bunlardan biridir. Tarihçi ve edebiyatçı Salah Birsel'in yaşadığı dönemin Beyoğlu'nu anlattığı Ah Beyoğlu Vah Beyoğlu adlı kitapta (1976) söz konusu durumu kanıtlayan bilgilere rastlanmaktadır. 1922 yılında Sadettin Arel tarafından çalgıya bir baş eşik eklenmesi, sonrasında ise keman ailesini örnek alarak polifonik müziğe elverişli şekilde bir beşleme oluşturma girişimi, çalgının kısa tarihi içerisinde öne çıkan bir diğer önemli denemedir (1948). 
Çalgının fasıl heyetine girmesinde etkili oldukları bilinen Vasil ve Tanburi Cemil sonrasında, kemençenin bugün adı anılan diğer ünlü icracıları, Anastas, Sotiri ve Leondarides isimli Rum icracılardır. Adı geçen isimlerle değişerek aktarılan icra geleneği, sonrasında Kemal Niyazi ve Cüneyd Orhon tarafından taşınmış, yirminci yüzyılın son çeyreğinde ise İhsan Özgen tarafindan yorumlanarak devam ettirilmiş, sonuç olarak geleneksel sanat müziğinden günümüz popüler müziğinin içinde yer alabilecek tüm alt türlere kadar yayılan geniş bir çevre ve repertuarda kullanım alanı bulmuş ve bugün sahip olduğu kimlik ve icra anlayışına kavuşmuştur.

\section{Araştırmaya Konu Olan Çalgının Tarihçesi ve Baron Baronak}

Araştırmaya konu olan çalgı; icracılık, araştırmacı yazarlık ve yayıncılık açısından değerli çalışmaları bulunan, Cumhurbaşkanlığı Klasik Türk Müziği Korosu Şefi Mehmet Güntekin'e aittir. Güntekin, çalgıyı biçemsel yönden, bir yapımcı gibi ayrıntılı şekilde değerlendirmeye yetecek ölçüde bilgisinin bulunmadığını (M. Güntekin, görüşme, 19 Temmuz, 2021) ifade etmekle birlikte, esasen kanun sanatçısı Hilmi Rit (d.1930 - ö.2009) ve Türk çalgıları konusundaki uzmanlığıyla tanınan organolog ve müzikolog Ethem Ruhi Üngör (d.1922 - ö.2009) aracilığı ile haberdar olduğu kemençenin, Baron yapımı olduğundan emin olduğunu ifade etmiştir. Rit ve Üngör, 70'li yıllarda İstanbul'a gelen İngiliz vatandaşı varlıklı bir Arap olan Faruk Fattah isimli koleksiyonerin, değerli çalgıları satın alarak, Londra'da bulunan koleksiyonuna kattığını, Baron yapımı üç kemençenin de söz konu çalgılar arasında yer aldığını, Sultan Abdülaziz'in cariyelerinden biri için adı geçen ustaya yaptırdığı çok özel işçilikli bir kemençenin de bu çalgılar arasında yer aldığını, Güntekin'le yaptıkları bir görüşmede üzüntüyle dile getirmişlerdir. Çalgının kendisine nasıl intikal ettiği hakkında ayrıntılı bilgi içeren bir blog yazısının (https://muhsinkitap.com/iki-baron-hikayesi, 2021) da bulunduğuna işaret eden Güntekin, Haldun Menemencioğlu tarafindan, Faruk Fattah ismli kişiye satılan kemençeyi, 2017 yılında, Kanada' da yaşadığını öğrendiği, yine Faruk Fattah'tan satın alarak ülkeye getirmiştir.

Aynı blog yazısında Baron ustaya ait kısa biyografik metin, özetle şu bilgileri içerir; 1834 yılında İstanbul Samatya'da doğmuştur. Ermeni cemaaitinin bir üyesidir. Önceleri marangozluk, dülgerlik ve kerestecilik gibi işlerle uğraşmış, daha sonra çalgı yapımcıllğı işine yönelmiştir. Yaptığ1 çalgıların ünü nedeniyle, Sultan Abdülaziz tarafindan sarayda ustabaşıllğa getirilmiştir. 'Baron' adı, esasen bir Ermeni adı olan 'Parunak' adından evrilmiş ve yerleşmiştir. Özellikle kemençe üretiminde mahir bulunsa da daha az sayıda ürettiği ud ve lavtalarla da erişilmesi güç bir ustalık seviyesindedir. Ses özellikleri bakımından kusursuz bulunan kemençelerinin tınısı, 'gür' ve 'tok' olarak nitelenmektedir. Ağaç işçiliğine ilişkin ince detaylar açısından dikkatli bir çalışma özelliği göstermeyen çalgıları, dönemin diğer ustaları tarafından tezyin edilmiş ve estetik seviyeleri oldukça yükseltilmiştir. Kemençe imâlinde tercih ettiği ağaç türleri; göğüs kısmı için selvi, tekne kısmı için ise abanoz, kanağacı, karadut, hintgülü, ardıç ve pelesenktir. Kendisinden sonra gelen yapımcılar sıklıkla kullanmış olsalar da kelebek, maun ve ceviz ağaçlarının kullanımını tercih etmemiştir. Çalgılarının süslemesinde sedef kullanımı yerine fildişi ya da fildişi ve bağa malzemelerini birlikte kullanmayı tercih ettiği görülmektedir.

\section{Görüşme Bulguları}

Temel amacı biçimsel değerlendirme olan bu araştırma aracılığıyla ulaşılacak tomografi verilerine, görüşme kişileri ile yapılacak sorgulama üzerinden elde edilecek, biçemsel özelliklerle ilgili söyleme dayalı bulgunun da eklenmesi amaçlanmıştır. Ne var ki araştırmaya konu olan çalgının orijinalliğini tartışmak ve bu konuda kesin bir sonuca ulaşmak, bu makalenin kapsamı dışındadır. Ancak bu yolda elde edilecek sözlü verinin, daha sonra ortaya konacak başkaca çalışmalarca değerlendirilerek zenginleştirilmesi, geleneksel çalgılarımız ve yapımcılarıyla ilgili birikimin nitelik ve niceliğini arttırma yönünde katkı sağlayıcı olacaktır.

$\mathrm{Bu}$ noktadan hareketle, 19-23.07.2021 tarihinde, çevrimiçi ortam olanakları ve telefon görüşmeleri üzerinden, kemençe yapımcılığı açısından geleneği temsil etme ve eski ustaların 
çalışma biçimleri ile onları öznel kılan unsurları nakletme açısından, görece temsil kaabiliyeti bulunan görüşme kişileri ile temas sağlanmış ve yapılan görüşmeler sonucunda, otantiklik isnadına aracılık etme bakımından çalgının bazı bölümlerinin öne çıkarıldığı anlaşılmıştır. Buna göre araştırmaya konu olan kemençede, kuyruk takozunun genel biçimi ve takoz üstü olukların derinlik ve biçim özelliklerine ilişkin genel durumu, sırt oluğunun genişlik ve derinliği ile genel biçimi, tekne bölümü dış formunun genel biçimsel özellikleri ile derinliği ${ }^{1}$ ve tekne ön görünümünün (koronal plan) genel biçimi, dikkatle ele alınarak yorumlanmıştır. Bu noktada kimi zaman söz konusu yorumlar ve bilginin aktarımı, zamanın diğer ustalarının yapımı olan çalgıların taşıdığı biçemsel özelliklerle mukayeseli olarak yapılmış, İzmitli ve Vasil yapımı kemençeler ile Baron yapımı bir kemençenin özellikleri, görüşme kişileri tarafindan karşılaştırılmıştır. Söz konusu karşılaştırmalı ele alış biçimi, farklı bir araştırmanın konusu olmak üzere bu makalenin kapsamı dışında bırakılmıştır. Bununla birlikte Baron yapımı kemençelerin İzmitli yapımı kemençelere göre daha kaba işçilikli oldukları üzerinde görüşme kişilerinin ortak bir görüş taşıdığı anlaşılmıştır.

Yerden'e göre araştırmaya konu olan çalgı, adı geçen ustanın biçemsel tercihleri ile kendisini öznel kılan unsurları önemli ölçüde yansıtmaktadır. Bu unsurlar değerlendirildiğinde araştırmaya konu olan kemençe, günümüz kemençelerine göre daha minyon, daha sığ bir biçim özelliğine sahiptir ${ }^{2}$. Kafa ve tuşe olarak adlandırılan kısımlar, günümüz kemençelerine göre daha dardır. Kafa eğimi ve sajital planda (bkz. Resim 18) ortaya çıkan genel biçim açısından çalgının eski ustaların üretimine has bir görünüm taşıdığını Rizeli de aktarmıştır (A. K. Rizeli, görüşme, 18 Temmuz 2021). Ustanın elinden çıkmış çalgıların en önemli işaretleyicilerinden biri olarak tel takozu, çalgının çalım esnasında diz üzerinde rahatça durabilmesine imkân verecek biçimde, yatık bir açıyla tasarlanmıs ve üç oluklu süsleme ile tamamlanmıștır. Çalgının bu bölümü ile ilgili olarak Rizeli de dizlik adını kullanarak benzer bir yorumla bu görüşe katılmıştır (A. K. Rizeli, görüşme, 18 Temmuz 2021). Ancak İnanç, tel takozu bölümünün altında devam eden sırt eğrisinin yan görünümünü (bkz. Resim 11) acemice ve hatalı bulmuş ve bu nedenle söz konusu çalgının, adı geçen ustanın kalfalık dönemi ürünü olabileceği yönünde bir yorumda bulunmuştur (M. İnanç, görüşme, 18 Temmuz 2021). Mihrap adı verilen bölge, yekpare olan çalgı gövdesine ayrı bir ek olacak biçiminde dahil edilmiştir. Ustanın kemençelerinde, diagram üzerinden yapılacak bir tarifle, A Planda (bkz. Resim 12), ses deliklerinden aşağıya doğru devam eden kıvrım, İzmitli adı ile anılan ustanın elinden çıkmış çalgılara göre, çok daha yuvarlak şekilde kavis almaktadır. Taç kısmı ise adı geçen ustanın ürettiği kemençelere göre daha kaba bir işçilik özelliği taşımaktadır. Bununla birlikte Baron ustanın çalgılarının sırt oluğu, Vasil ustanın elinden çıkanlara göre daha sı̆̆, tekne dış bombesi ise daha kabarıktır (M. Yerden, görüşme, 20 Temmuz, 2021). Kemençenin biçemsel açıdan değerlendirilmesi noktasında genel silüet, tel takozu, mihrap, taç, sırt oluğu gibi bölümler ile tekne eğrilerinin (aksiyal plan görüntüleri bkz. Resim 17) önemli olduğunu dile getiren Karakaya da Baron ustaya isnad edilen kemençelerin çoğunun, ustanın, kendinden sonra gelen yapımcılar tarafindan takip edilmiş olması sebebiyle aslında taklit olduğunu ${ }^{3}$, çalgının teknesinde, adı geçen ustaya ait bir imza ya da etiket bulunmaması halinde, bu konuda kesin hükümler taşıyacak bir görüş bildirmenin cesaret gerektirdiğini aktarmıştır. Ne var ki Haluk Recai'nin tanıklık ve görüşüne işaret edecek biçimde, çalgının teknesinde bulunan eski (1968) bir tamirat etiketi, Karakaya’ya

\footnotetext{
${ }^{1}$ Sajital planda, koronal plana göre eksen noktasında ortaya çıkan genel görünüm. Bu görünüm aynı zamanda yapımcılar tarafından, çalgının tekne formuna ilişkin genel görünümün elde edilmesine olanak sağlayan 'yan şablona' ulaşma amaciyla da kullanılmaktadır

${ }^{2}$ Söz konusu farkın, özellikle kemençe sanatçısı İhsan Özgen'in tını arayışıyla ilişkili olarak çalgının genel biçimi üzerindeki denemeleri ile birlikte, çalgının kullanıldığı müzik geleneği içerisinde ortaya çıkan değişimle başlayan ses arayışı neticesinde kalıcı hale gelen bir etkiyle ilişkili olduğu aktarılmıştır. Fasıl müziği içerisinde sesini duyurabilecek dişi karakterdeki yüksek ses gürlügüne sahip bir çalgı yerine, daha koyu tınılı çalgılar üretmek üzere akustik bölgenin iki ucu olarak tanımlanan kafa ve tel takozu bölgelerindeki ağırlık bilinçli olarak arttırılmıştır (M. Yerden görüşme, 2021).

${ }^{3} \mathrm{Bu}$ konuya Ahmet Kadri Rizeli de değinmiş ve Haluk Recai'nin, elden geçirdiği çok sayıda eski kemençenin içine, çalgının daha fazla önem görmesini sağlamak amacıyla Baron yapımı olduğunu ifade eden bir not eklediğini de dile getirmiştir.
} 
göre bu kemençenin Baron ustanın yapımı olduğu ihtimalini arttırmaktadır (F. Karakaya, görüşme, 23 Temmuz, 2021).

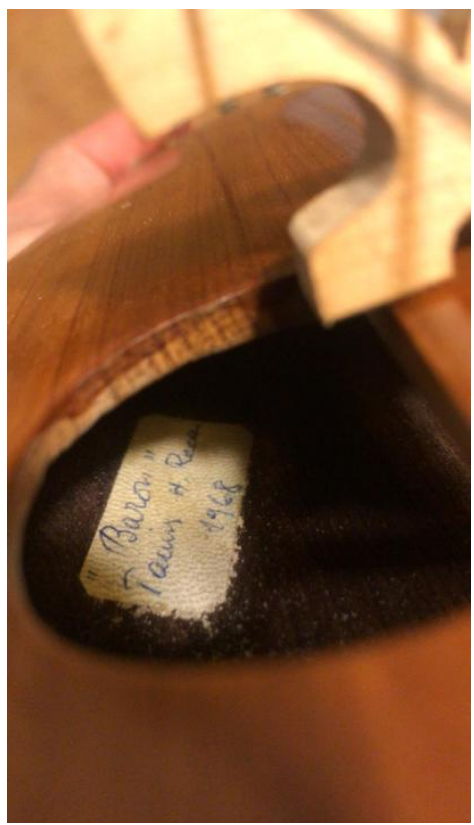

Resim 1: Haluk Recai'ye ait, "Baron” Tamir H. Recai 1968 ifadesini taşıyan etiketin fotoğraf görüntüsü.

\section{Araştırmaya Konu Olan Çalgının Fotoğrafları}

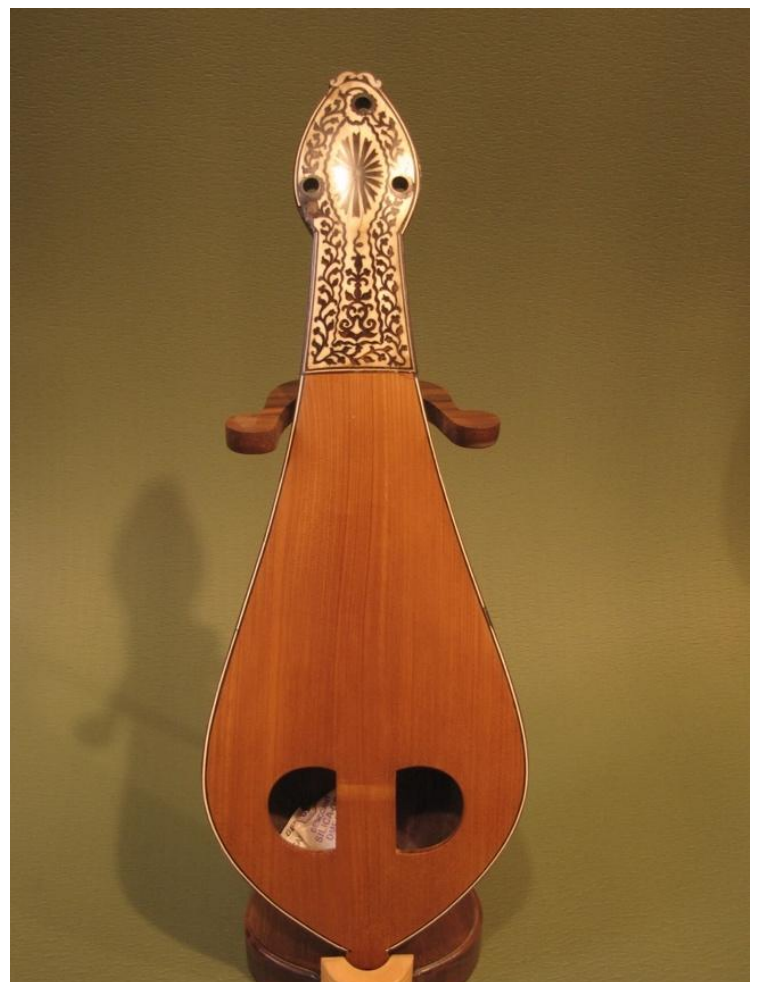

Resim 2: Kemençenin Ön Plan Fotoğraf Görüntüsü 


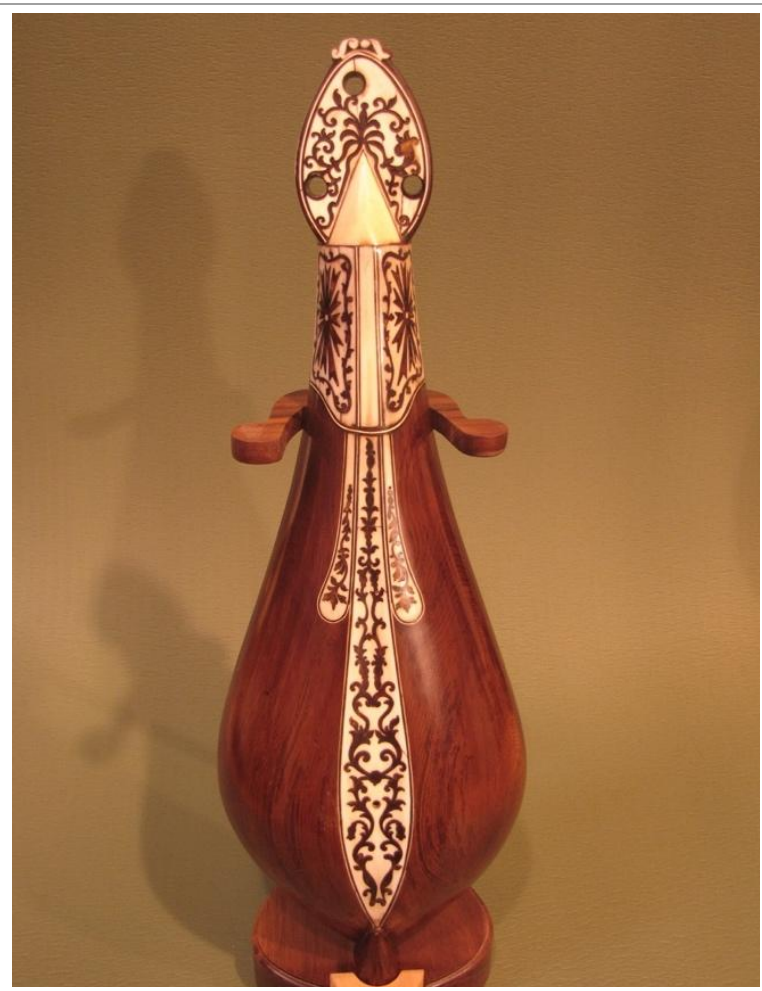

Resim 3: Kemençenin Arka Plan Fotoğraf Görüntüsü

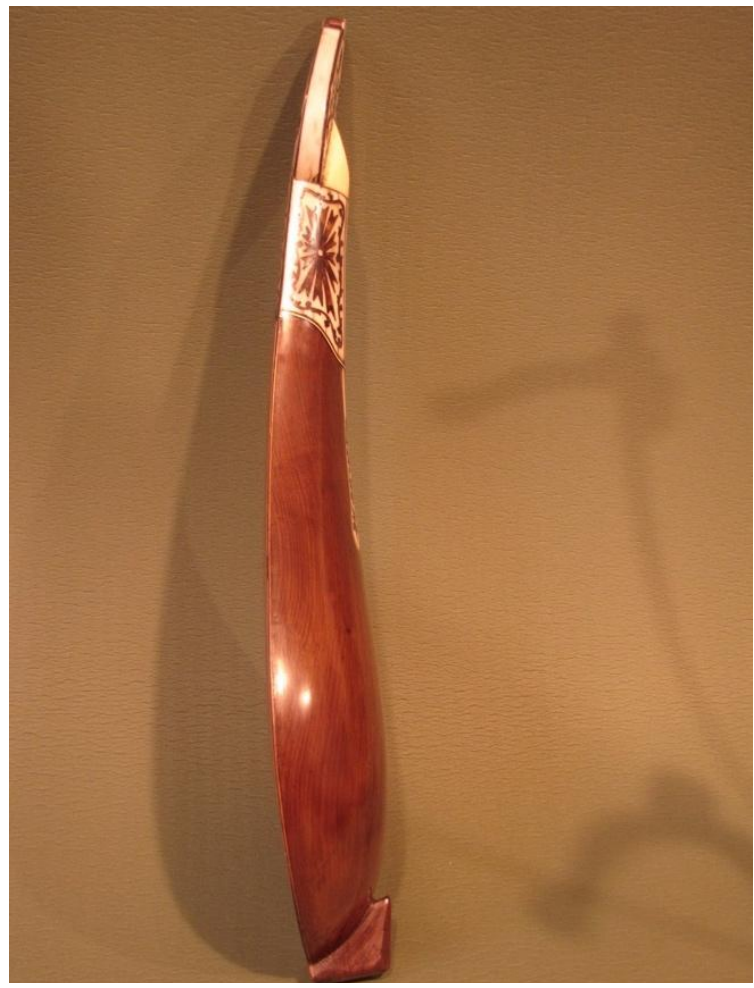

Resim 4: Kemençenin Yan Plan Görüntüsü 


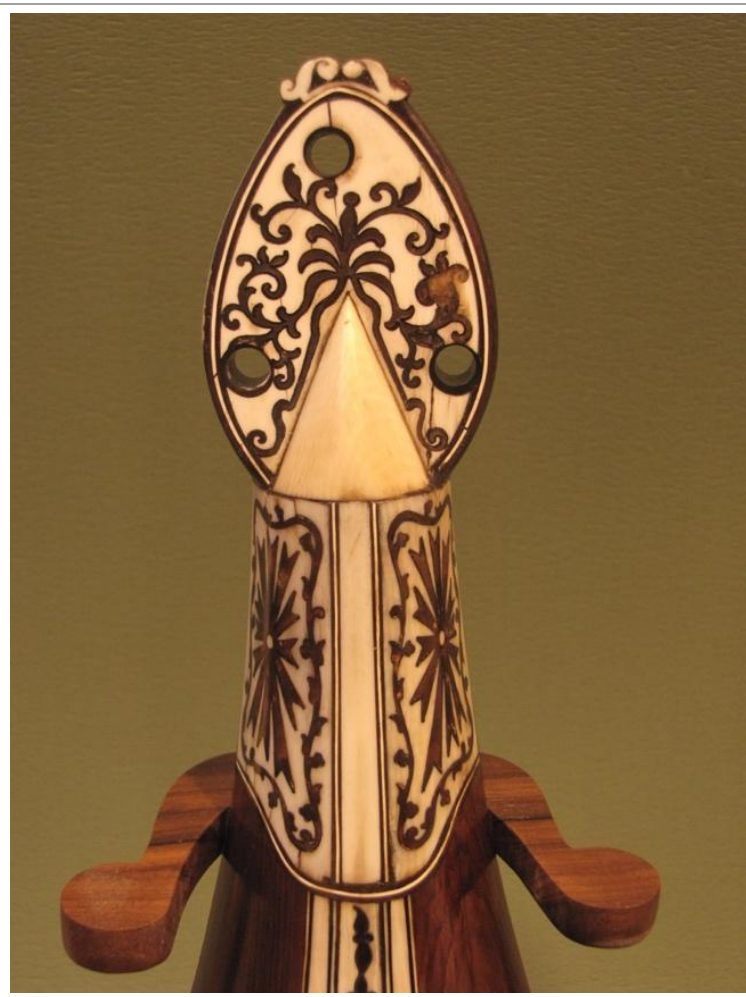

Resim 5: Kemençenin Sap Arkasının Yakın Plan Görüntüsü

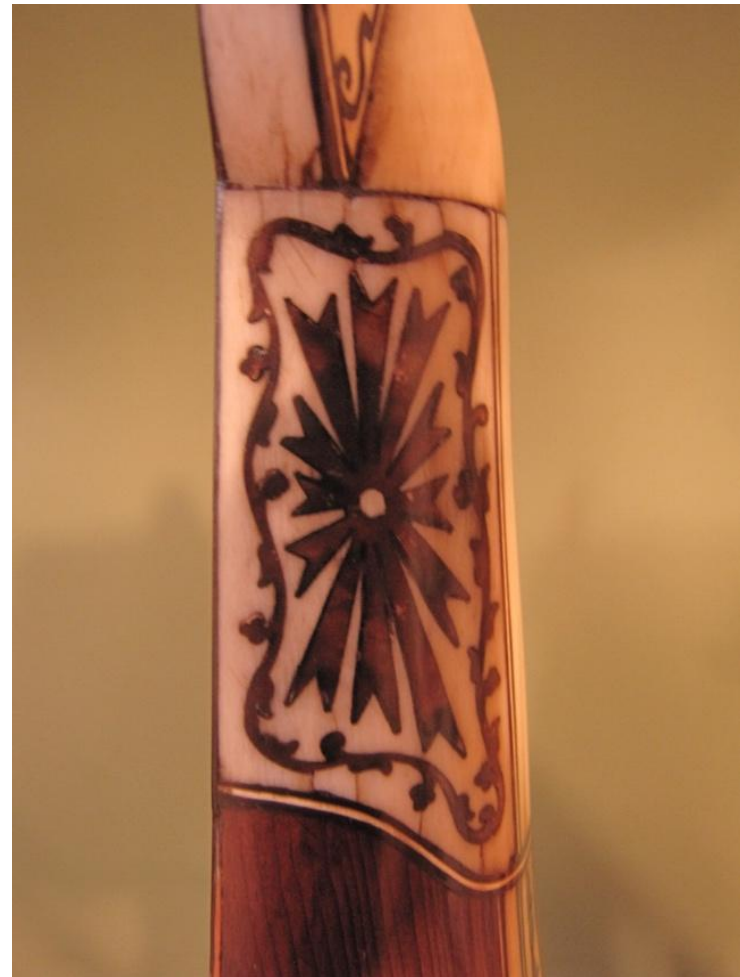

Resim 6: Kemençenin Sap Arkasının Yakın Plan Görüntüsü 


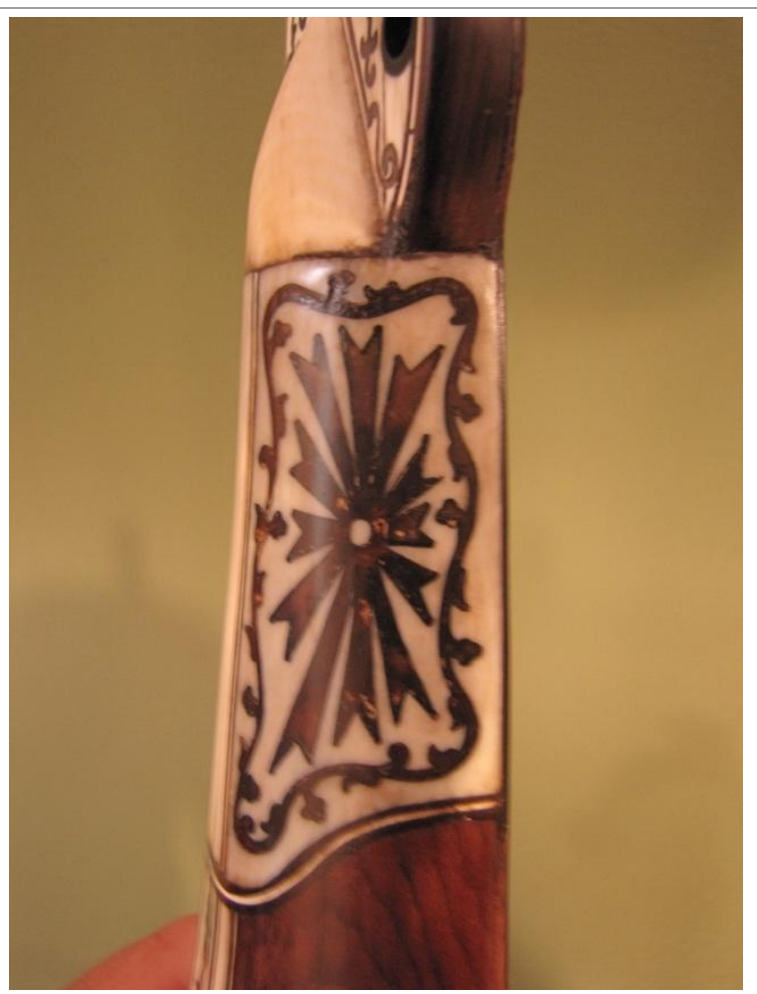

Resim 7: Kemençenin Sap Arkasının Yakın Plan Görüntüsü.

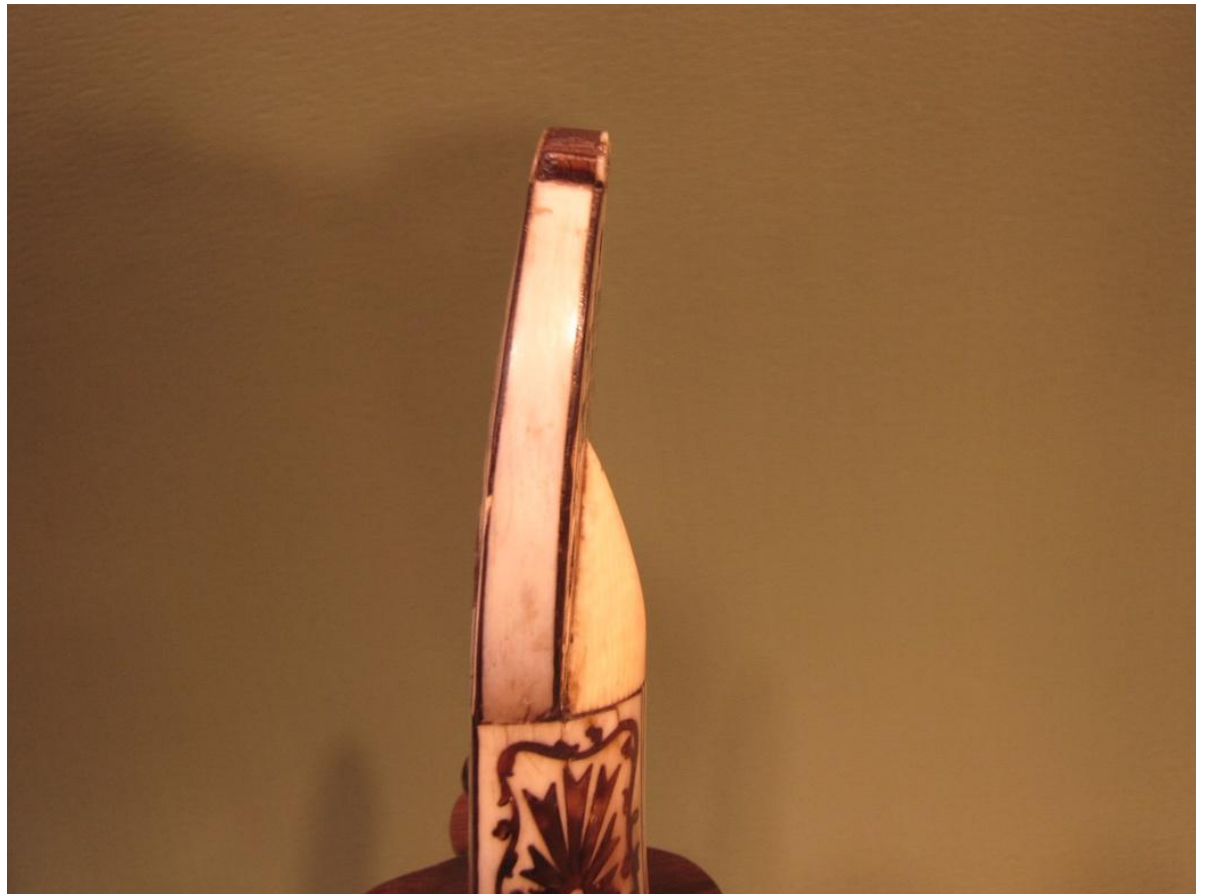

Resim 8: Kemençenin Burguluk kısmının Yakın Plan Yandan Görüntüsü 


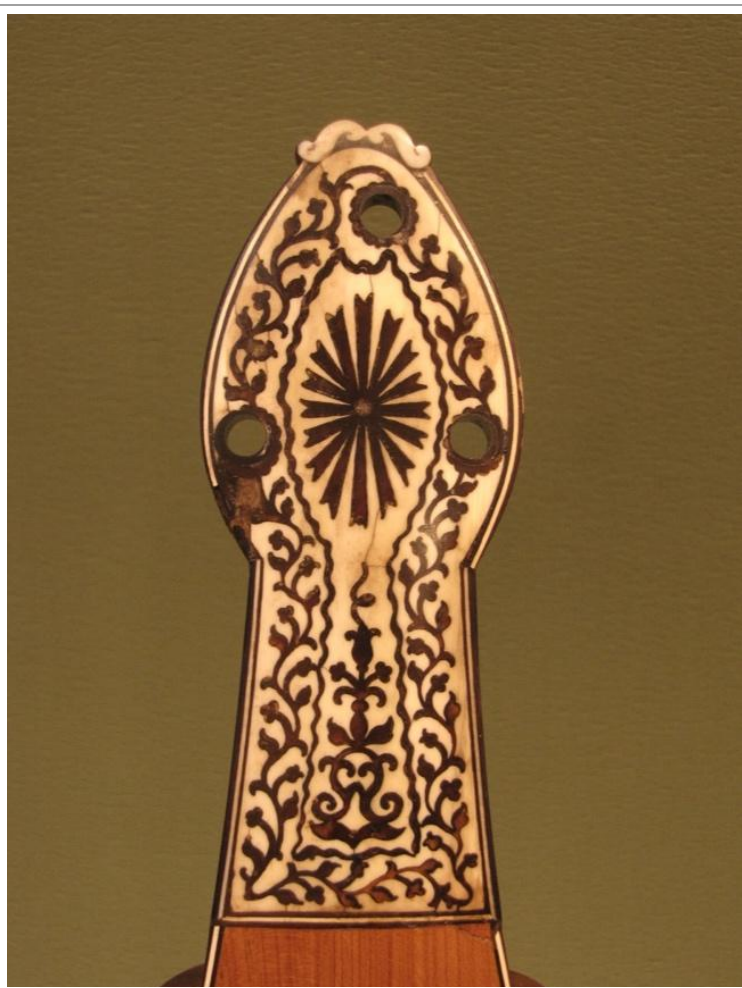

Resim 9: Kemençenin Tuşesinin Yakın Plan Görüntüsü

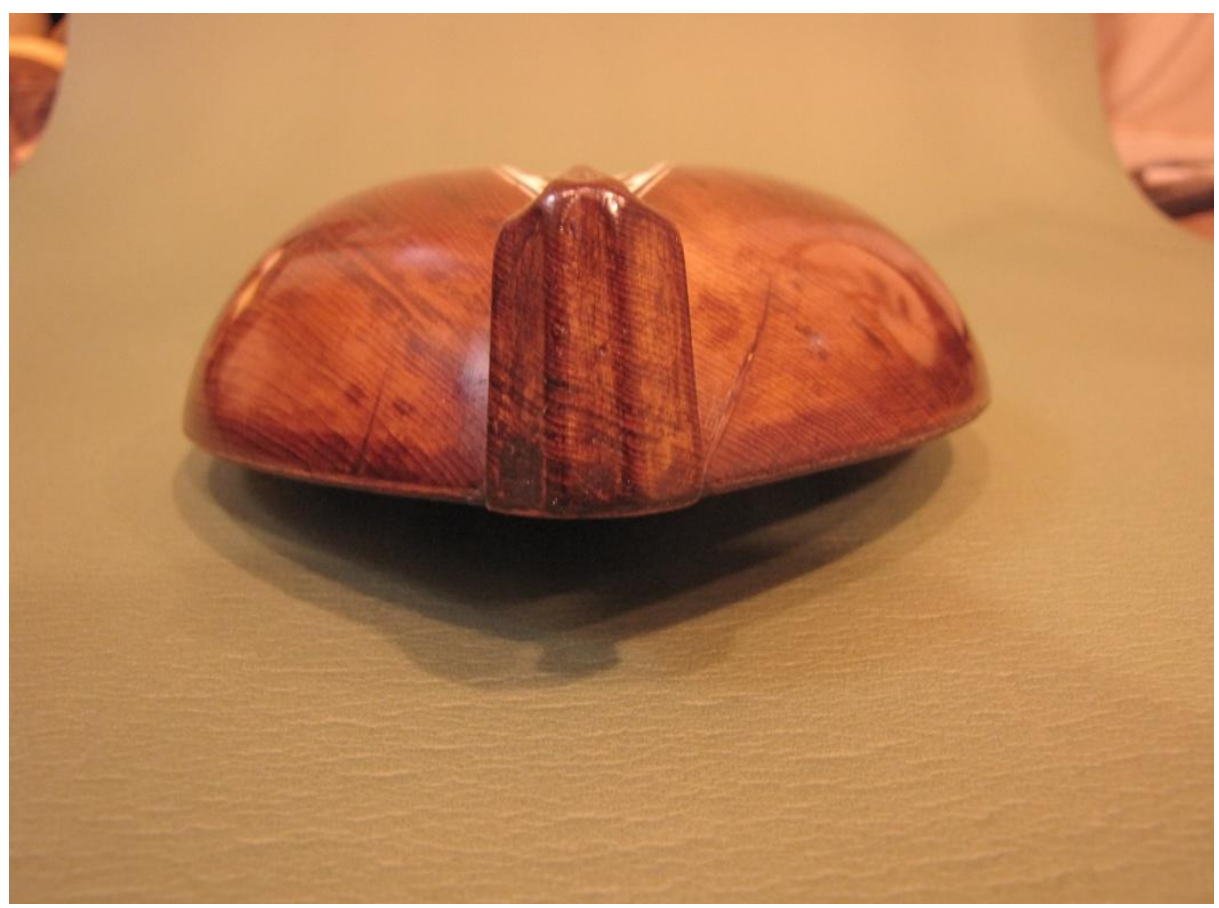

Resim 10: Kemençenin ve Kuyruk Takozunun Alttan Görünümü 


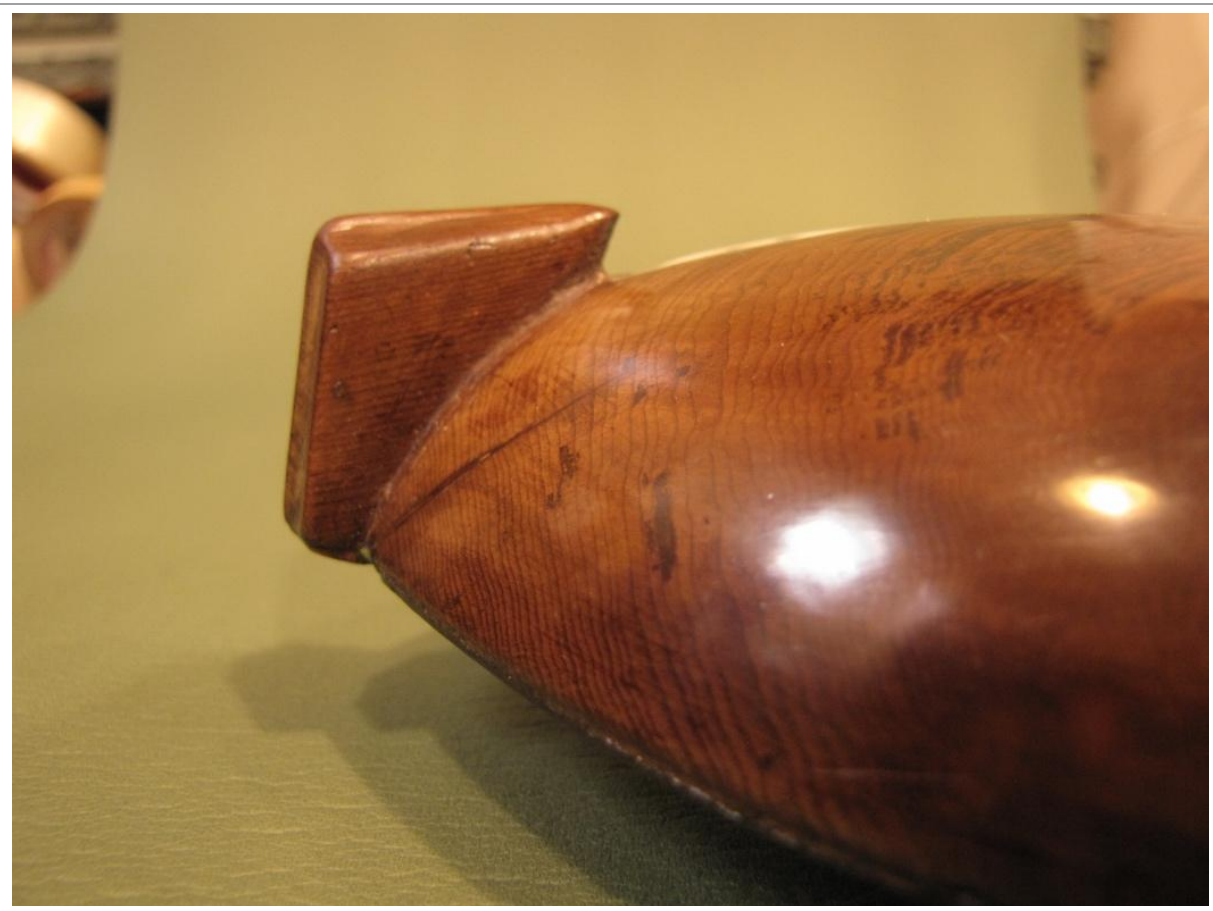

Resim 11: Kemençenin Kuyruk Takozunun Yandan Görüntüsü

Yapım Malzemesine İlişkin Bilgi ve Temel Yapım Ölçüleri

Yapım Malzemesi:

Ses Tablası: Selvi / Cupressus

Tekne: Ardıç / Juniperus Communis

Flato: Süt Taşı ve Pelesenk

Tuşe: Bağa ve Kemik

Yapım Ölçüleri: 


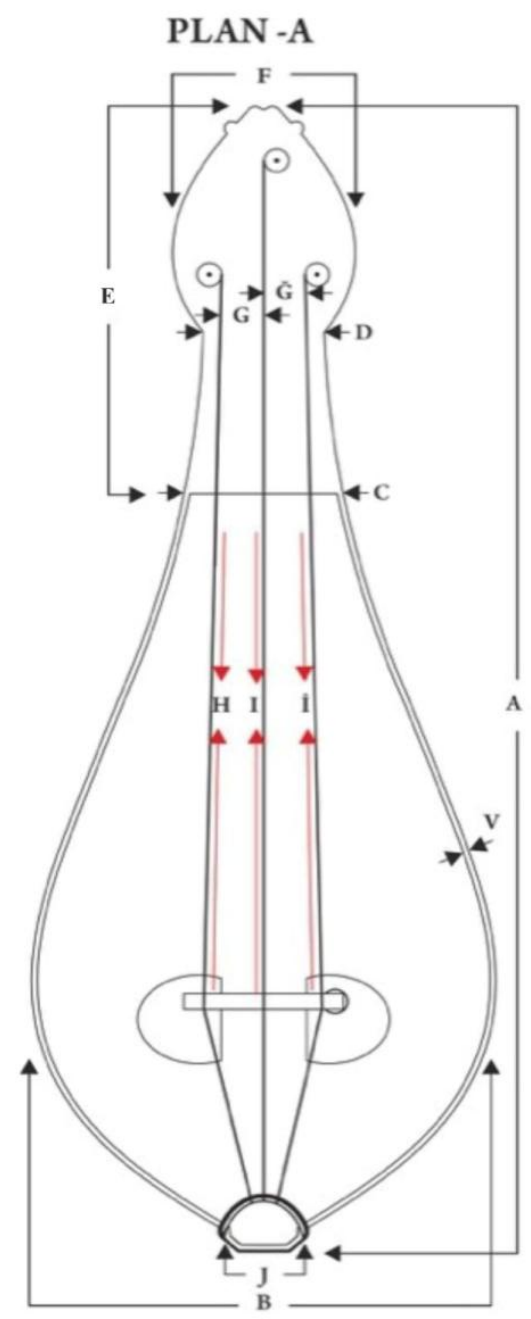

Resim 12: Plan " $A$ " 


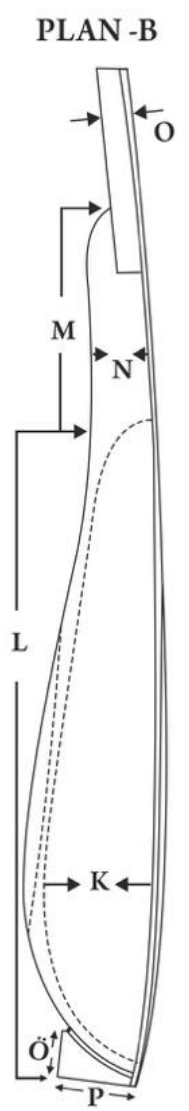

Resim 13: Plan " $B$ "

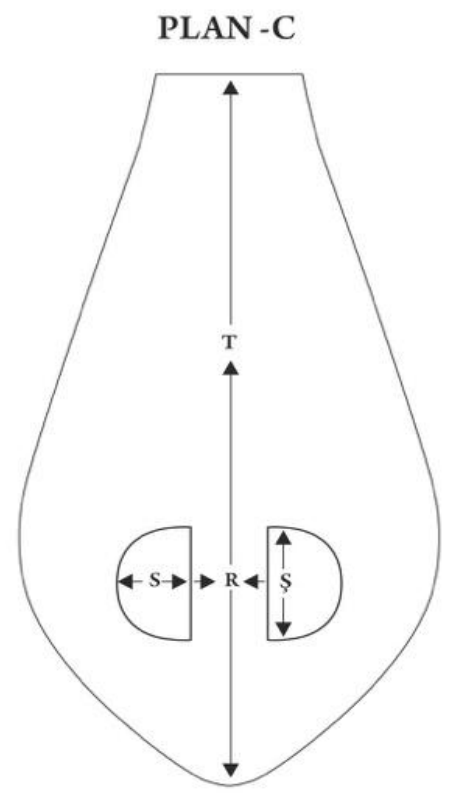

Resim 14: Plan "C"

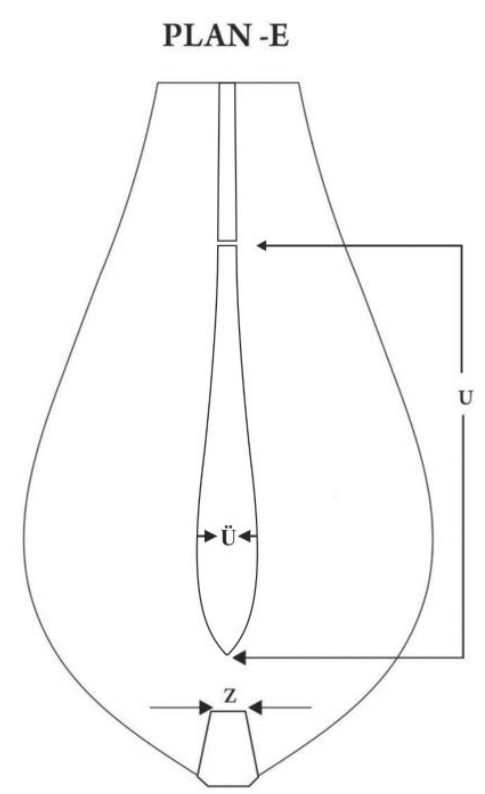

Resim 15: Plan "E” 


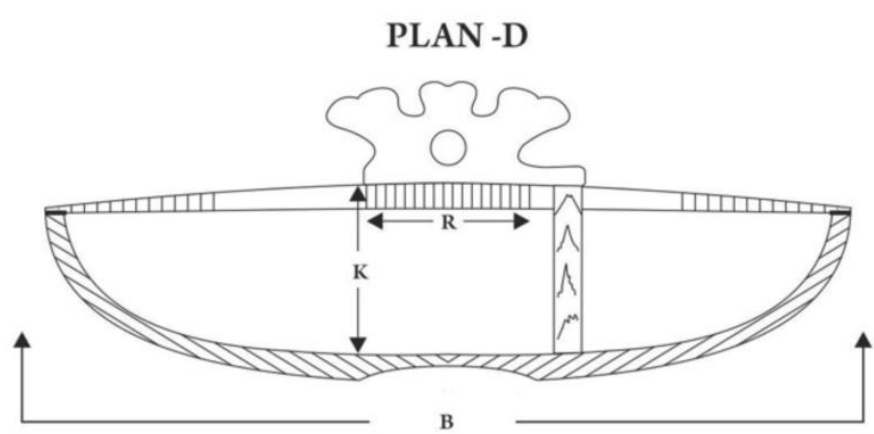

Resim 16: Plan " $D$ "

Tablo 1: Temel Yapım Ölçüleri

\begin{tabular}{cccccccccccc}
\hline A & $407 \mathrm{~mm}$. & F & $55.8 \mathrm{~mm}$. & I & $262 \mathrm{~mm}$. & N & $27.8 \mathrm{~mm}$. & S & $29 \mathrm{~mm}$. & V & $2.5 \mathrm{~mm}$. \\
\hline B & $140.9 \mathrm{~mm}$. & G & $15 \mathrm{~mm}$. & J & $21 \mathrm{~mm}$. & O & $12.6 \mathrm{~mm}$. & Ş & $40 \mathrm{~mm}$. & Z & $6 \mathrm{~mm}$. \\
\hline C & $49.8 \mathrm{~mm}$. & G & $15 \mathrm{~mm}$. & K & $32 \mathrm{~mm}$. & Ö & $29.1 \mathrm{~mm}$. & T & $258 \mathrm{~mm}$. & & \\
\hline D & $38.6 \mathrm{~mm}$. & H & $262 \mathrm{~mm}$. & L & $246 \mathrm{~mm}$. & P & $31.7 \mathrm{~mm}$. & U & $216 \mathrm{~mm}$. & \\
\hline E & $135 \mathrm{~mm}$. & I & $301 \mathrm{~mm}$. & M & $989 \mathrm{~mm}$. & R & $25.7 \mathrm{~mm}$. & Ü & $30 \mathrm{~mm}$. & \\
\hline
\end{tabular}

Tablo 2: Ölçüm Bölgelerine İlişkin Harf Tablosu

\begin{tabular}{|c|c|c|c|c|c|c|c|c|c|c|c|}
\hline A & Form boyu & $\mathrm{F}$ & $\begin{array}{l}\text { Tuşe üst } \\
\text { genişliği }\end{array}$ & $\dot{I}$ & $\begin{array}{l}\text { Neva teli } \\
\text { uzunluğu }\end{array}$ & $\mathrm{N}$ & $\begin{array}{c}\text { Sap } \\
\text { kalınlığ }\end{array}$ & $\mathrm{S}$ & $\begin{array}{c}\text { Ses } \\
\text { deliği } \\
\text { genişliği }\end{array}$ & V & $\begin{array}{l}\text { Bordür } \\
\text { genişliği }\end{array}$ \\
\hline B & Form eni & $\mathrm{G}$ & $\begin{array}{l}\text { Yegâh ve rast } \\
\text { teli aras1 }\end{array}$ & $\mathrm{J}$ & $\begin{array}{l}\text { Kuyruk } \\
\text { genişliği }\end{array}$ & $\mathrm{O}$ & $\begin{array}{l}\text { Burguluk } \\
\text { kalınlığ } 1\end{array}$ & Ş & $\begin{array}{c}\text { Ses } \\
\text { deliği } \\
\text { yüksekli } \\
\text { ği } \\
\end{array}$ & $\mathrm{Z}$ & $\begin{array}{l}\text { Kuyruk arka } \\
\text { genişliği }\end{array}$ \\
\hline C & $\begin{array}{c}\text { Tuşe alt } \\
\text { ucu }\end{array}$ & $\breve{G}$ & $\begin{array}{l}\text { Rast ve neva } \\
\text { teli arası }\end{array}$ & $\mathrm{K}$ & $\begin{array}{c}\text { Tekne } \\
\text { derinliği }\end{array}$ & Ö & $\begin{array}{c}\text { Kuyruk } \\
\text { yüksekliğ } \\
\text { i }\end{array}$ & $\mathrm{T}$ & $\begin{array}{c}\text { Kapak } \\
\text { boyu }\end{array}$ & & \\
\hline $\mathrm{D}$ & $\begin{array}{c}\text { Tuşe orta } \\
\text { k1sım }\end{array}$ & $\mathrm{H}$ & $\begin{array}{l}\text { Yegâh teli } \\
\text { uzunluğu }\end{array}$ & $\mathrm{L}$ & $\begin{array}{l}\text { Tekne } \\
\text { boyu }\end{array}$ & $\mathrm{P}$ & $\begin{array}{c}\text { Kuyruk } \\
\text { derinliği }\end{array}$ & $\mathrm{U}$ & $\begin{array}{c}\text { Damla } \\
\text { boyu }\end{array}$ & & \\
\hline E & Tuşe boyu & I & $\begin{array}{l}\text { Rast teli } \\
\text { uzunluğu }\end{array}$ & M & Sap boyu & $\mathrm{R}$ & $\begin{array}{l}\text { Sirt oluğu } \\
\text { genişliği }\end{array}$ & $\ddot{U}$ & $\begin{array}{l}\text { Damla } \\
\text { genişliği }\end{array}$ & & \\
\hline
\end{tabular}

\section{Bilgisayarlı Tomografi Tarama Bulguları}

Araştırmaya konu olan kemençenin bilgisayarlı tomografi cihazı ile aksiyal planda taranmış olması sebebiyle, tarama sonuçlarını incelemek üzere yine aksial plan (bkz. Resim 19) tercih edilmiştir. Söz konusu tercihin nedeni, bu plana ait görüntülerin, geriçatma sonucu oluşturulan koronal (bkz. Resim 21) ve sajital (bkz. Resim 20) planlara göre daha iyi bir sonuç vermesidir. 


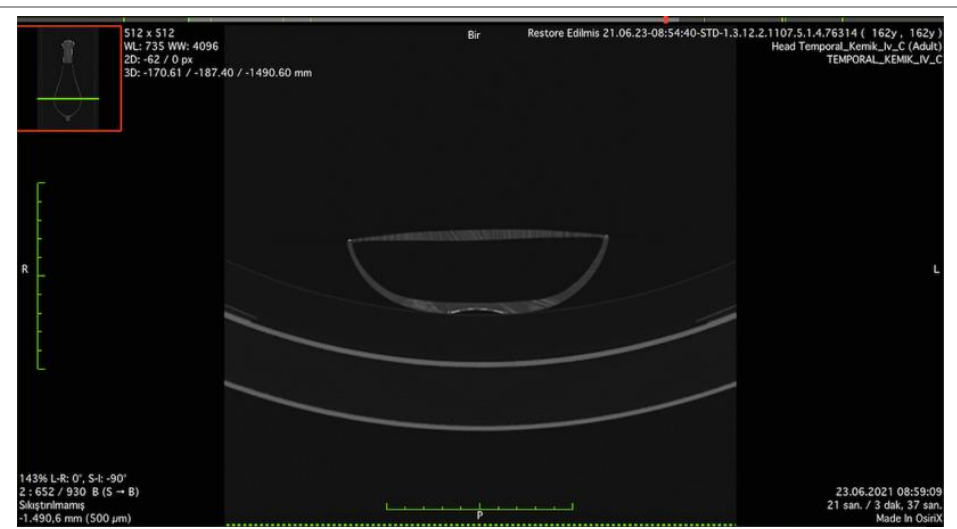

Resim 17: Aksiyal Plan Görünümü

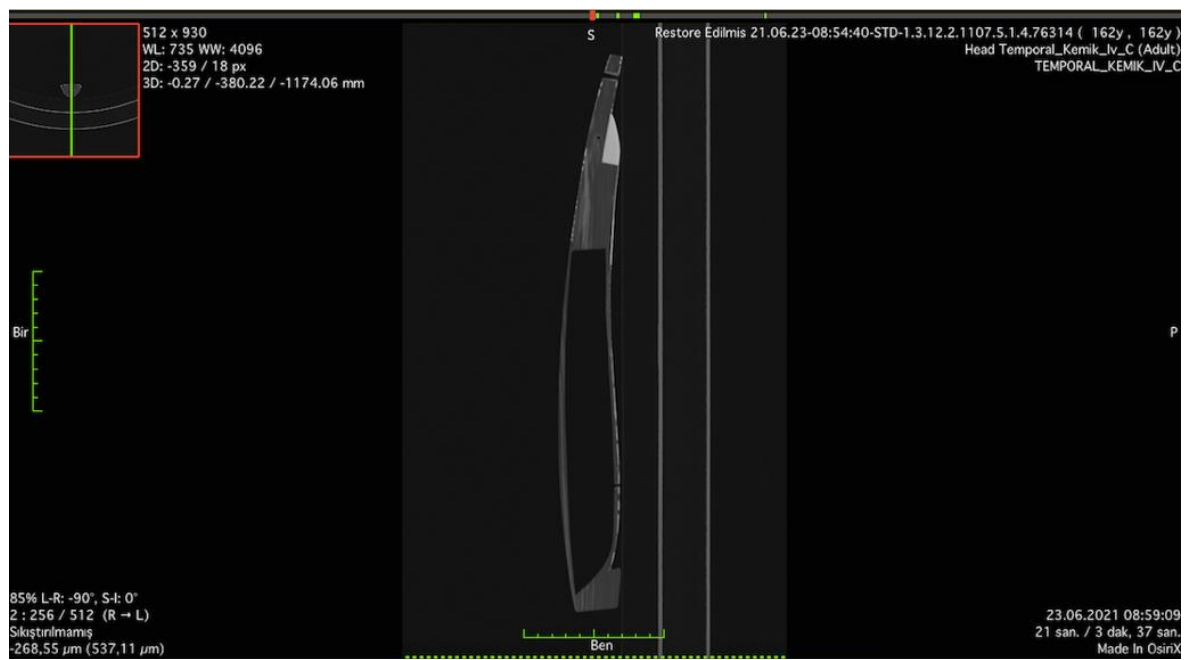

Resim 18: Sajital Plan Görünümü

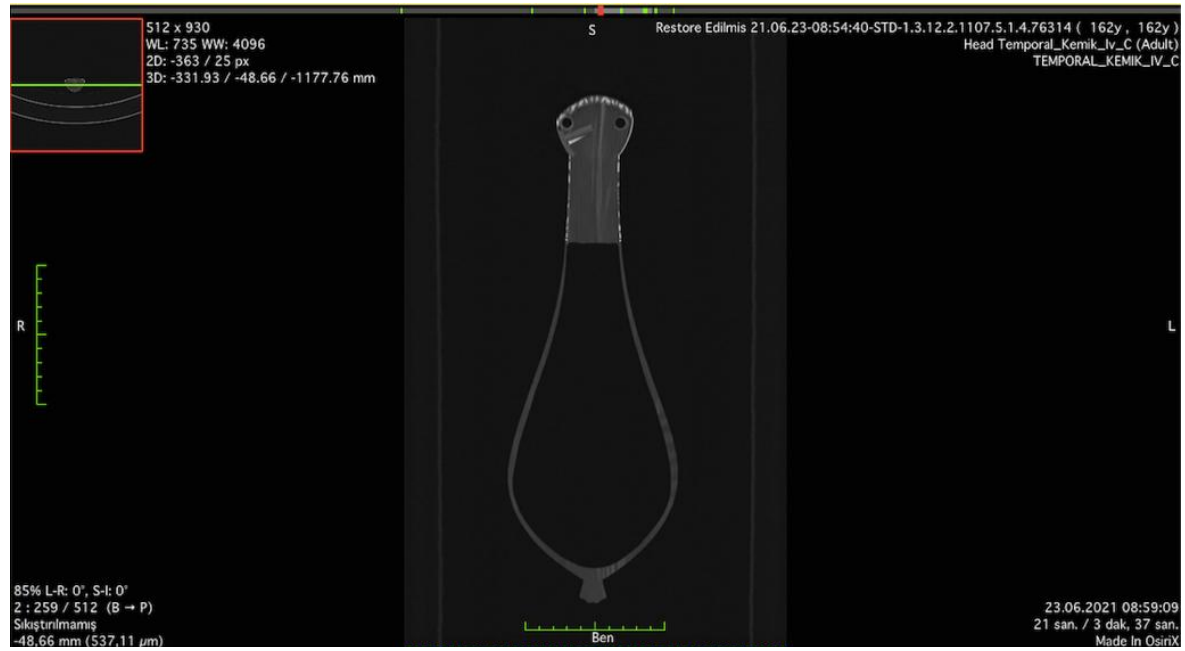

Resim 19: Koronal Plan Görünümü

Kuyruk takozu yönünden başlanan inceleme, bu bölüm boyunca çalgının yapımında kullanılan ahşabın, ses tablası yönünde daha kalın ve heterojen, aksi yönde ise daha ince ve homojen bir yapıda olduğunu göstermektedir. 


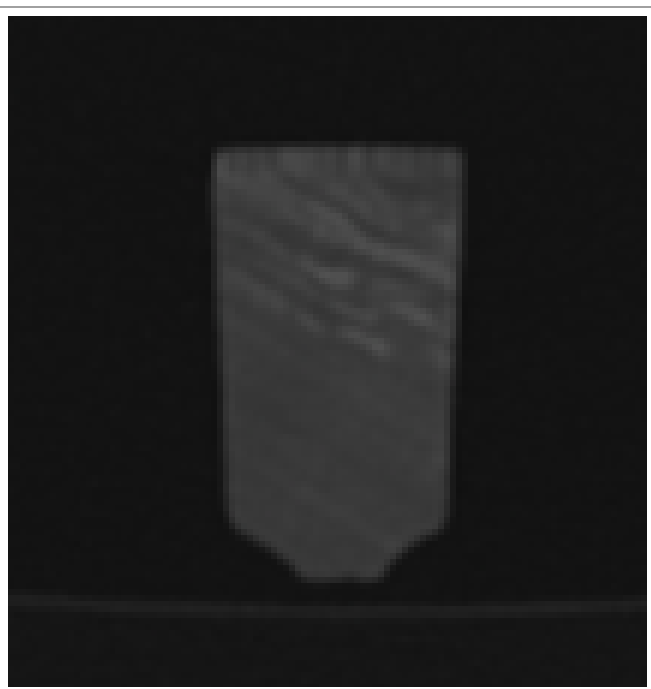

Resim 20: Kuyruk Takozu Aksiyal Plan Detay Görünümü

Damar yapısının bu plana göre dik olacak bir eksen çizgisine göre yaklaşık 20 derecelik bir açıyla devam ettiği gözlemlenmiştir. Bununla birlikte takoz bölümü ile birlikte gözlemlenen, ses tablasına ait damar yapısı ise bundan farklı şekilde eksene dik olacak bir açı özelliği ile takozu takip etmektedir.

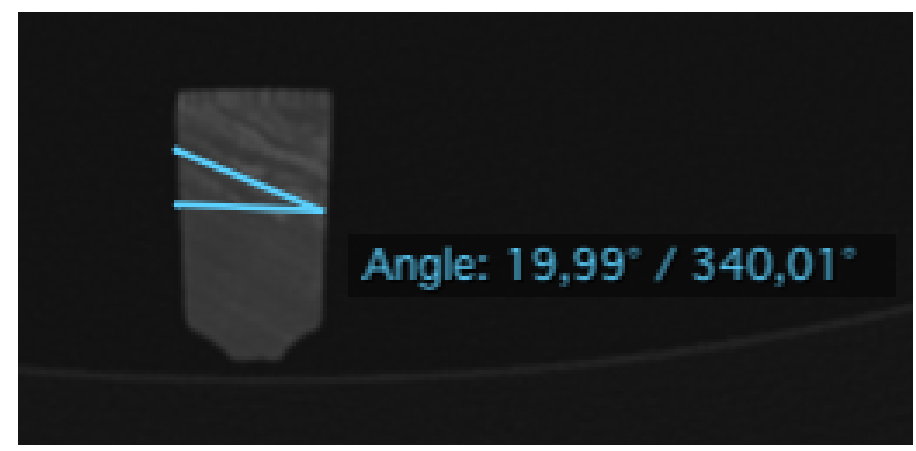

Resim 21: Kuyruk Takozu Aksiyal Planda Damar Yapısı Görünümü

Takip eden bir başka görüntü, flato olarak adlandırılan kısma aittir ve gerek görüntü gerekse yoğunluk ölçümleri, söz konusu bölgenin yapımında kullanılan malzemenin, ses tablası ve kuyruk takozu için kullanılan malzemeye göre çok daha yüksek bir yoğunluk özelliğine sahip olduğunu ifade eder niteliktedir. 


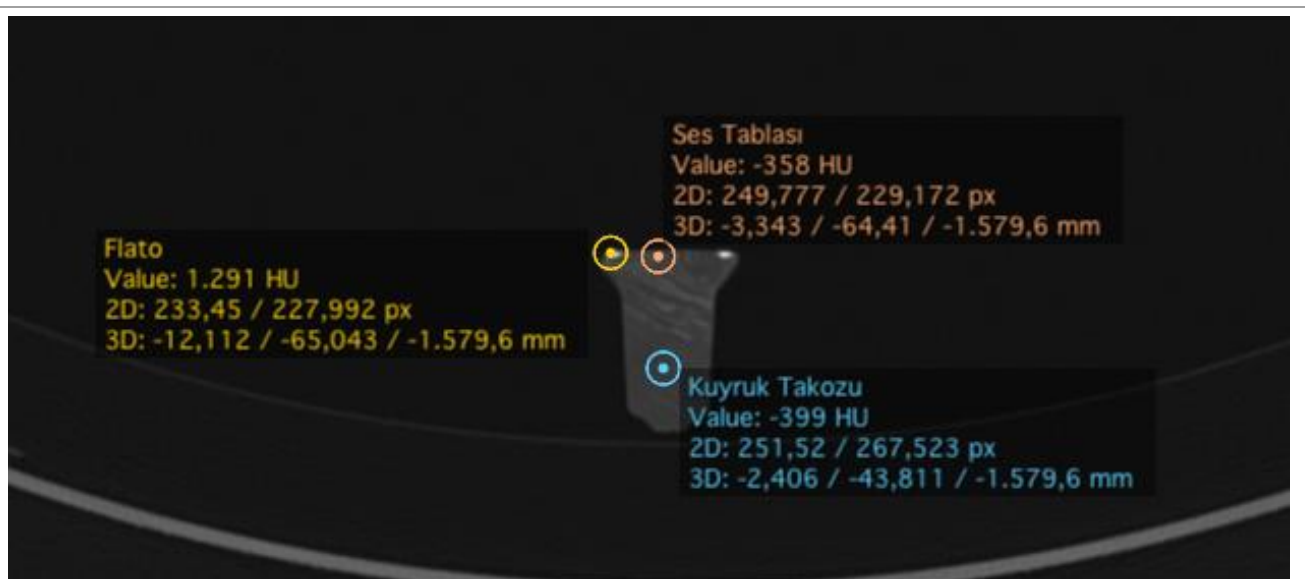

Resim 22: Flato Ses Tablası ve Kuyruk Takozuna Ait Noktasal Yoğunluk Değerleri.

Kuyruk takozu üzerinde bulunan ve bu inceleme aracıllğıyla kesit görüntülerine ulaşılan oluk yapısı, zamana bağlı biçimde oluşan aşınma nedeniyle, takozun orta kısmında daha derin bir şekil yapısı (bkz. Resim 25) sergilemektedir. Bununla birlikte başlangıç bölgesinde daha geniş bir şekil yapısına sahip kuyruk takozu, devam eden bölgeye doğru incelmekte ve içe doğru kavisli bir yap1 sergileyecek şekilde sonra ermektedir. Söz konusu bölge dahilinde olan tüm ahşap yap1 içerisinde, herhangi bir özür ya da onarım izi görülmemiştir.
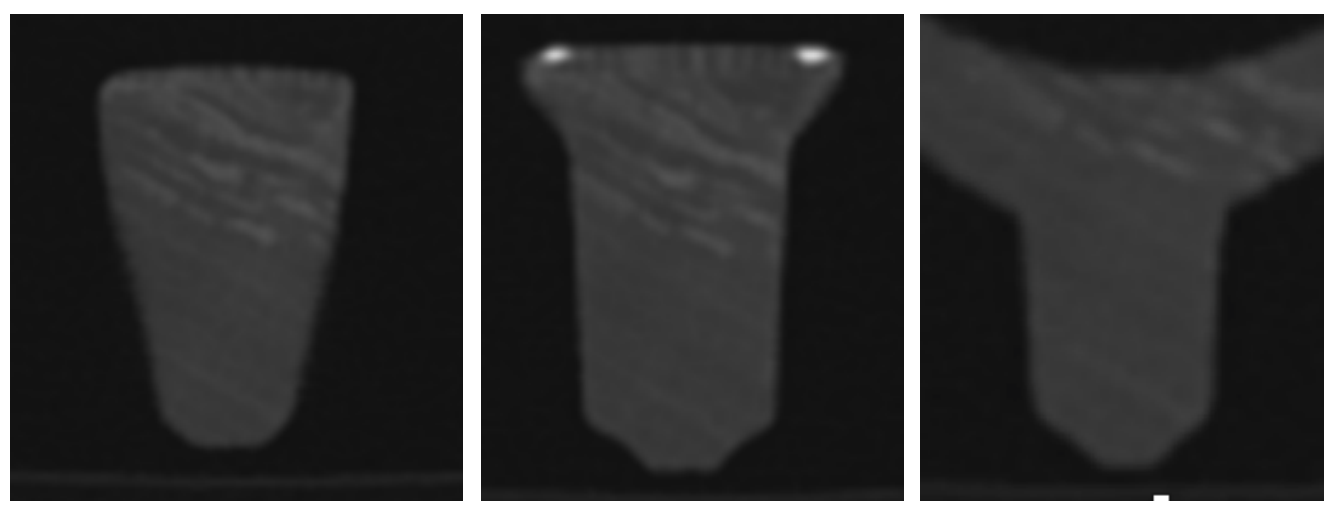

Resim 23: Kuyruk Takozu Oluk Yapısına Ait Kesit Görünümler

Kuyruk takozu bölümünün ardından tekne içi ya da ses kutusu olarak adlandırılabilecek bölümün kesit görüntülerine geçilmiştir. Söz konusu bölümde sağ (R/right) ve sol (L/left) yönde, hemen ortaya çıkan iki görüntü (bkz. Resim 26-27), odun anatomisine ilişkin terminolojiye göre öz kesitte, öz ışını olarak tanımlanan (Ergün, 2019: 52) yapı yönüne paralel olacak biçimde seyreden, çatlak ya da boşluk benzeri iki kusurun bulunduğunu göstermiştir. 


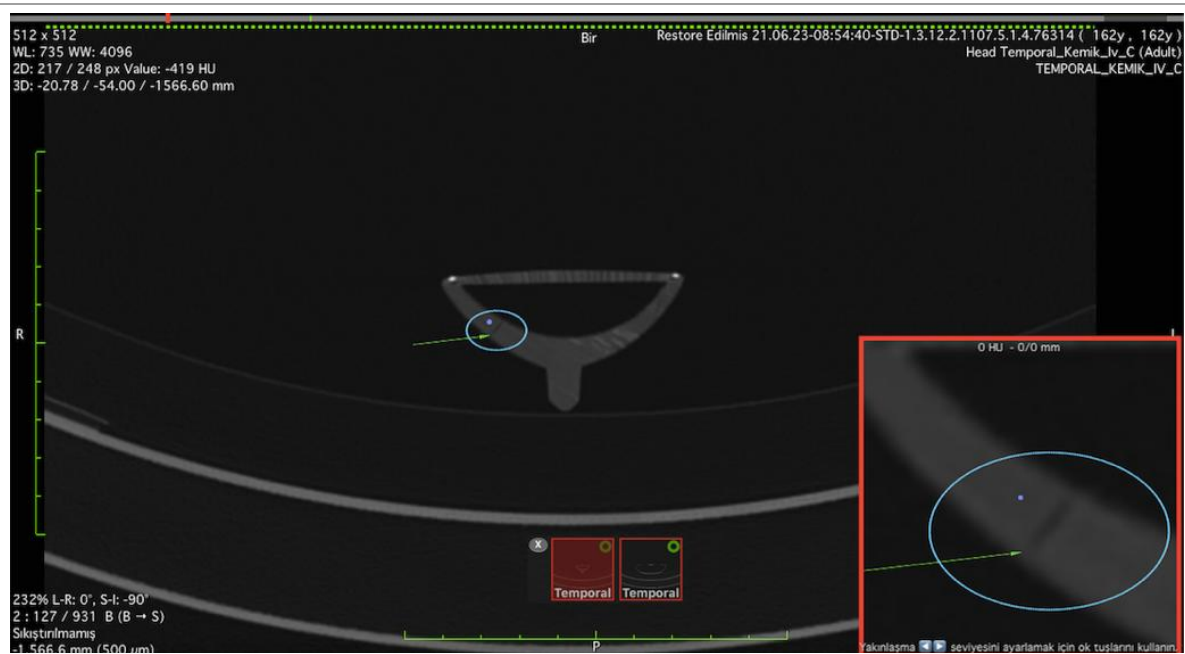

Resim 24: Çatlak Bulunan Bölgeye Ait Kesit Görünüm.

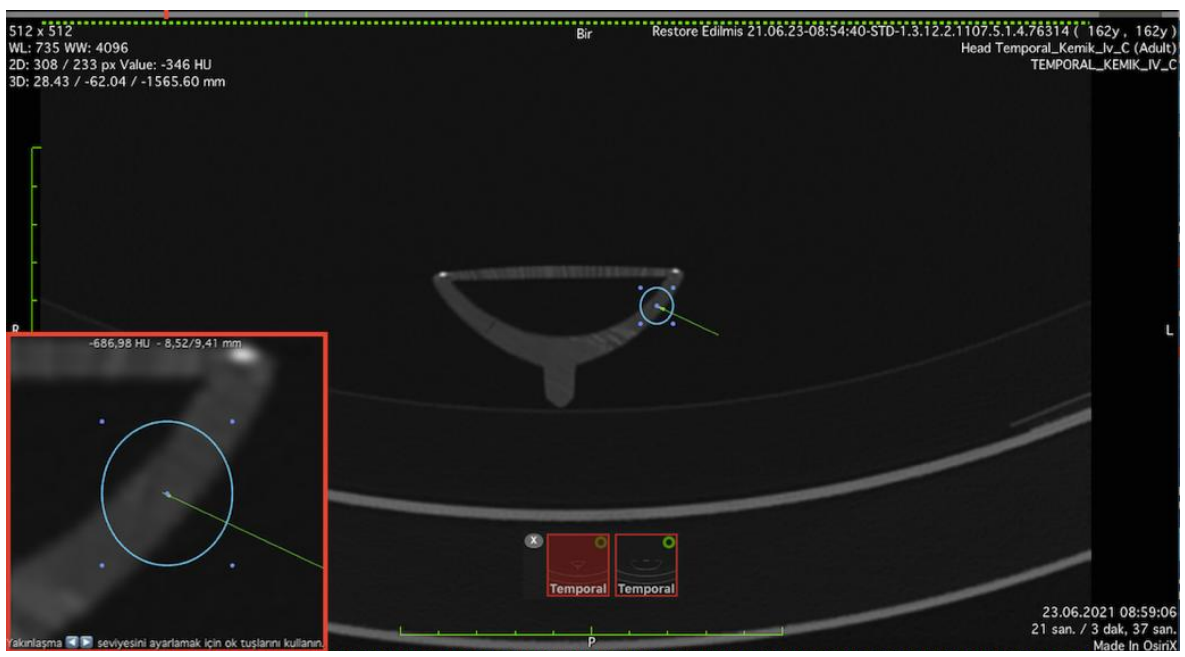

Resim 25: Çatlak Bulunan Bölgeye Ait Kesit Görünüm

Makale içerisinde daha önce paylaşılan resim 9 ve 10 aracılığ 1 ile de görülebilecek bu kusurların, çalgının yapımında kullanılan ahşap malzemenin kuruması sürecinde kendiliğinden ortaya çıkmış olma ihtimali bulunduğu gibi bir darbe, bası ve ezilme sonucu ortaya çıkmış olmaları da muhtemeldir. Ses kutusunun aksiyal plana göre genişleyerek takip eden bölgelerinde, sirt oluğu olarak isimlendirilen kısmı süsleme amacıyla kullanılan malzemenin, flato işçiliğinde kullanılan malzeme ile yakın bir yoğunluk değerine sahip olduğu görülmektedir (bkz. Resim 28). Yoğunluk durumunun tespitine yönelik olarak yapılan lokal ölçümler de görüntü farkını destekleyecek bir bilgi sunacak niteliktedir. 


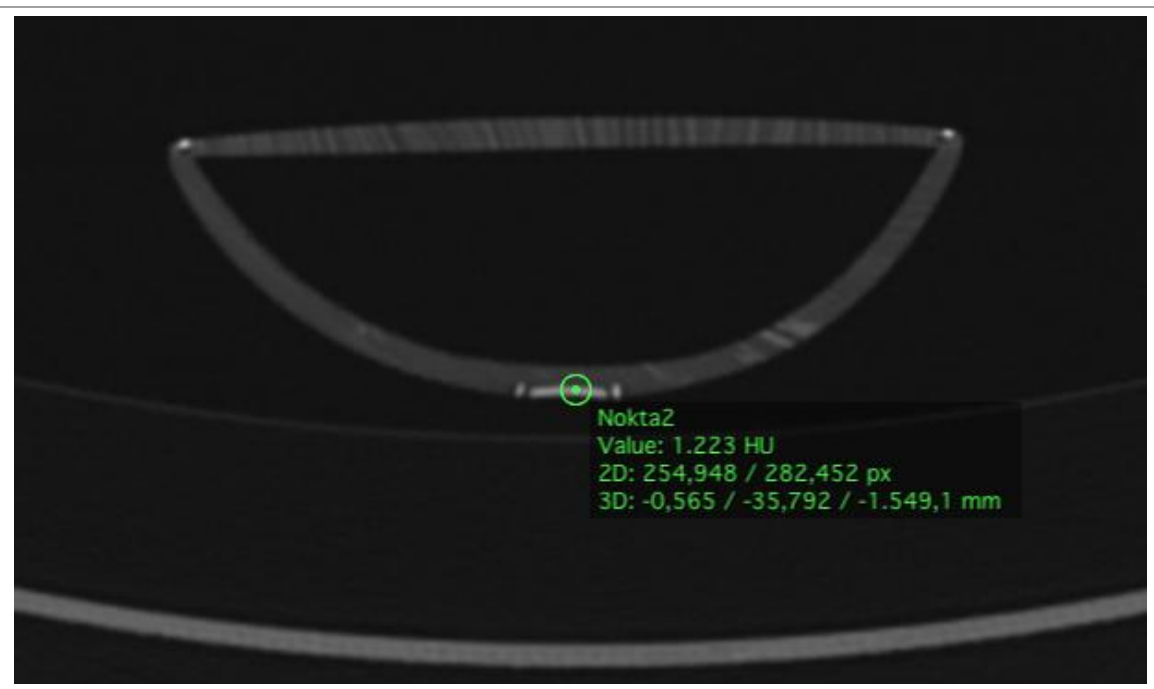

Resim 26: Surt Oluğu Süsleme Malzemesi Noktasal Yoğunluk Değeri

Giderek iç bükey bir form kazanan sırt oluğu, çalgının sap kısmına doğru bu formunu kaybedecek biçimde devam etmektedir (bkz. Resim 29-30-31).

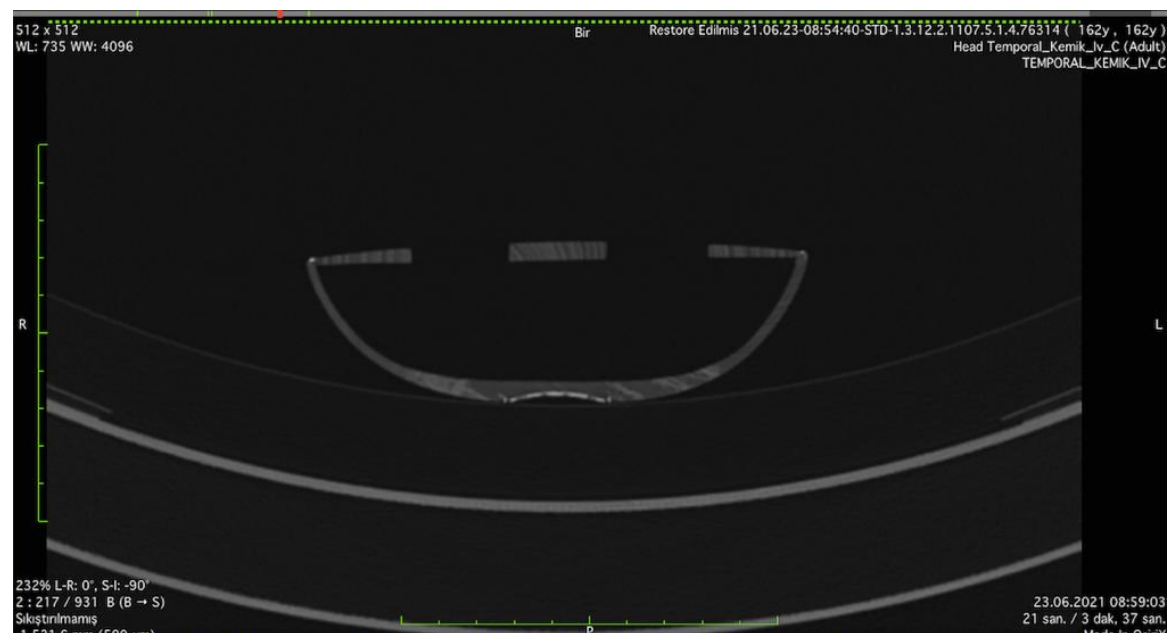

Resim 27: Sirt Oluğu Kavisi Kesit Görünümü

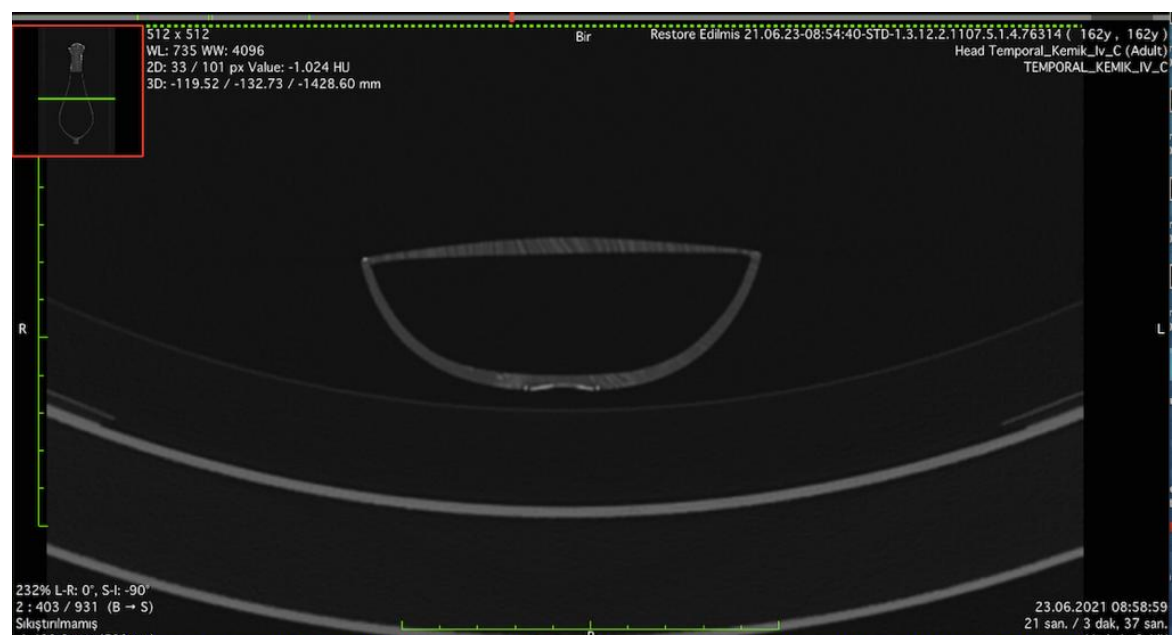

Resim 28: Sırt Oluğu Kavisi Kesit Görünümü

www.turkishstudies.net/turkishstudies 


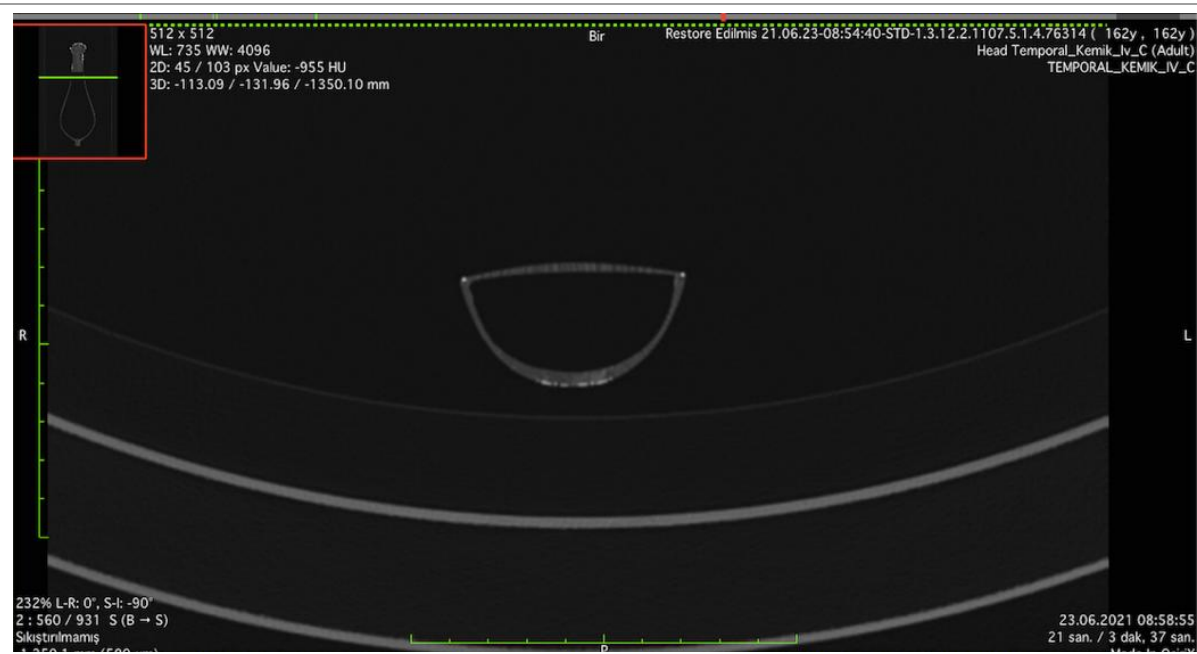

Resim 29: Sırt Oluğu Kavisi Kesit Görünümü

Ses tablasının yapımında kullanılan ahşap malzeme, damar yapısına ilişkin görsel özellikler açısından başlangıç kısmı ile benzer biçimde devam etmiş ve herhangi bir kusurlu bölge içermeksizin sap bölgesinde sona ermiştir. Çalgının sap bölgesinde yapılan incelemelerde flato ve sırt oluğu süslemelerinde kullanılan malzemeyle eşdeğer yoğunluk özelliğine sahip malzemenin kullanımının tuşe/klavye bölümünde de (bkz. Resim 32-33) devam ettiği, kusur ya da onarım olarak değerlendirilebilecek bir görüntünün ortaya çıkmadı ğı gözlemlenmemiștir. Bununla birlikte mihrap bölgesinde de (bkz. Resim 34) eş değer yoğunluğa sahip malzemenin kullanımının devam ettiği görülmektedir.

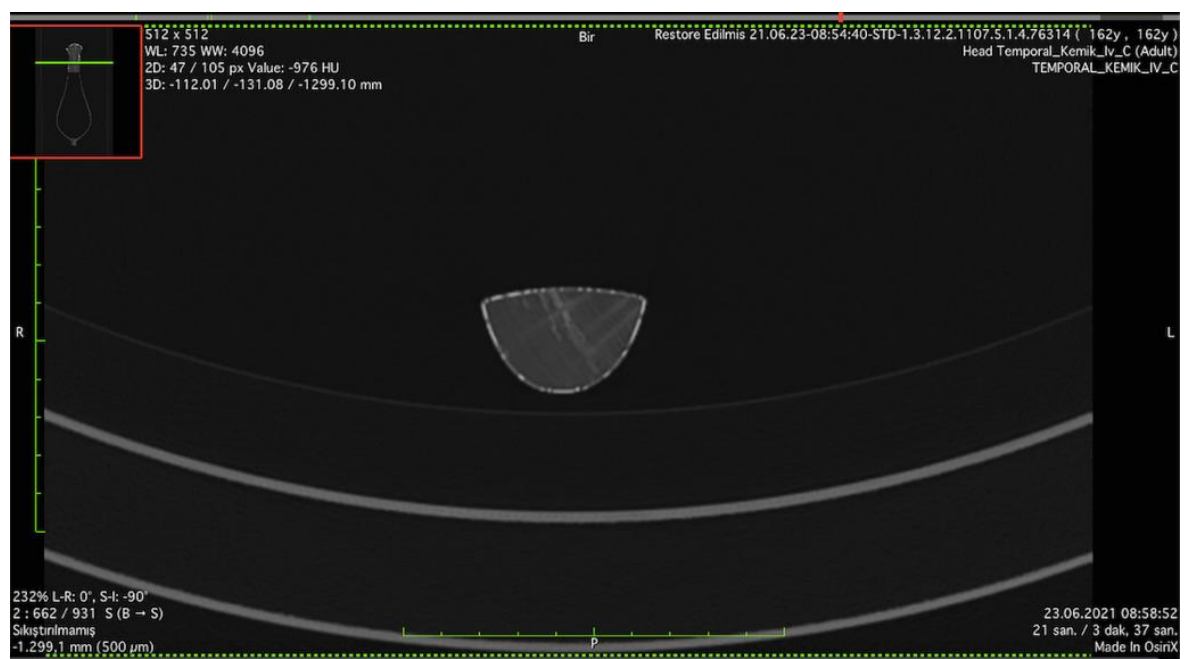

Resim 30: Sap Bölümüne Ait Bir Kesit Görünüm 


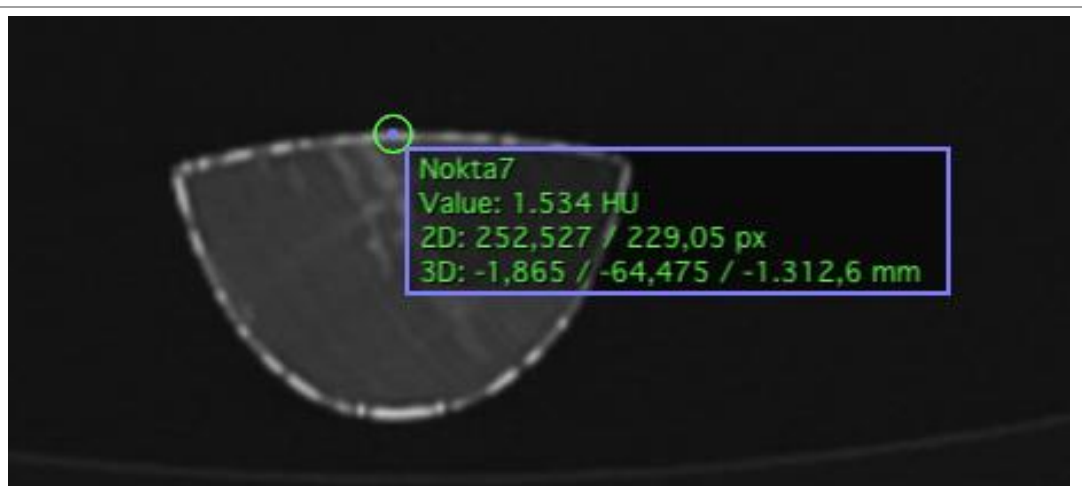

Resim 31: Tuşe Süsleme Malzemesine Ait Noktasal Yoğunluk Değeri

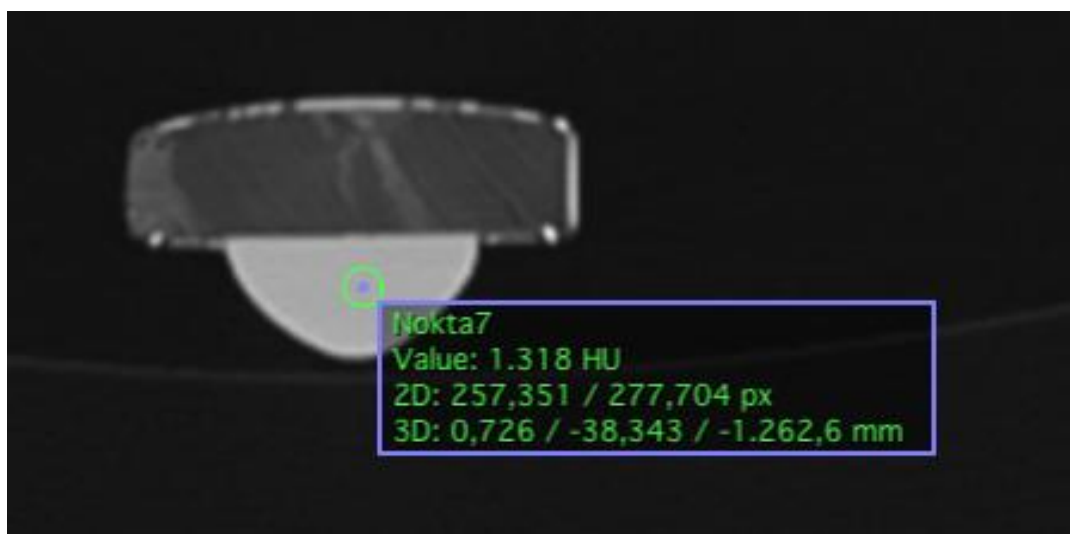

Resim 32: Mihrap Bölgesine Ait Noktasal Yoğunluk Değeri

Çalgının burguluk kısmında ise burguluğu kaplayan yüksek yoğunluklu malzemenin altında kalacak biçimde iki önemli tamirat bölgesiyle karşılaşılmış, söz konusu onarımların, çalgının burguluk bölümüne ait ahşap yapının içerisinde belirgin biçimde gözlemlenebilen boşluklar bırakacak şekilde tamamlanmış ve onarımın, bir parça ahşabın bölgeye eklenerek tamamlandığ 1 anlaşılmıştır. Söz konusu bölgeye ve konu edilen bulgulara ait detay fotoğrafları (bkz. Resim 35-36) aşağıda sunulmaktadır.

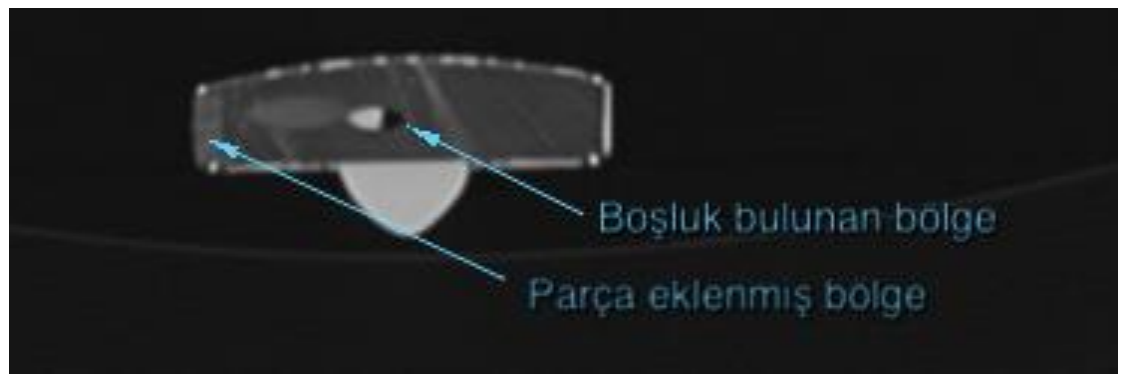

Resim 33. Onarım Bölgesine Ait Kesit Görünüm 


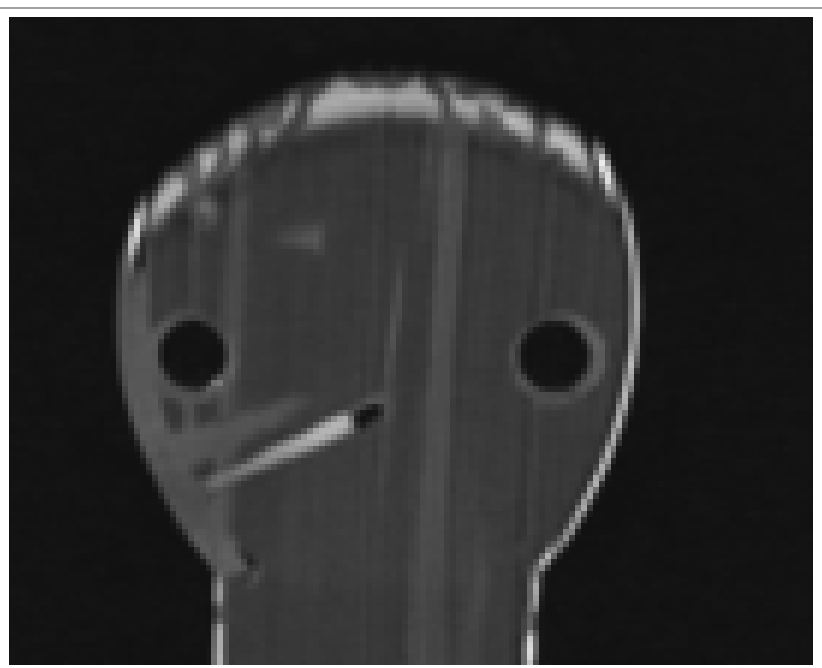

Resim 34: Onarım Bölgesine Ait Koronal Planda Kesit Görünüm

\section{Sonuç}

Yapılan görüşmeler, kişilerin araştırmaya konu olan çalgının biçemsel özellikleri ile yapımcısı arasında ilişki kurduğunu göstermiştir. Görüşme kişileri, çalgının biçemsel özelliklerine gönderme yapmak üzere belirli bölgeleri ‘özellikle' dikkate alarak yorumlamaya yönelmiştir. Bu noktada kuyruk takozu ve genel biçimi, takoz üstü oluklar, sırt oluğunun genel biçimi ve derinliği, sajital planda tekne biçimi, koronal planda tekne biçimi, ses deliklerinin biçimi, mihrap uygulaması, burguluk kalınlığı, sap genişliği ya da kafa yapısı gibi bölgeler ve bunlara ait bilgilerin, söz konusu biçemsel unsurlarla ilişkili biçimde, görüşme kişileri tarafından 'dikkatle' gözlemlenerek değerlendirilen temel konular oldukları görülmektedir. Aşağıda sunulan tablo aracılığıyla, görüşme kişileri tarafından ortaya konan bu bilgi ve değerlendirme, kategori ve nicelik açısından daha somut şekilde ele alınabilir.

Tablo 3: Biçemsel değerlendirme açısından yorumlanan bölgeler

\begin{tabular}{|c|c|c|c|}
\hline & Bölge & & Bilgi \\
\hline \multirow[b]{2}{*}{1} & \multirow[b]{2}{*}{ Takoz } & 1 & Genel biçim \\
\hline & & 2 & Tokuz üstü olukların genel biçimi ve derinliği \\
\hline \multirow{2}{*}{2} & \multirow{2}{*}{ Sirt oluğu } & 3 & Genel biçimi \\
\hline & & 4 & Surt oluğu genel biçimi ve derinliği \\
\hline \multirow{2}{*}{3} & \multirow{2}{*}{ Tekne } & 5 & Sajital planda tekne biçimi \\
\hline & & 6 & Koronal planda tekne biçimi \\
\hline 4 & Ses delikleri & 7 & Genel biçim \\
\hline \multirow{2}{*}{5} & \multirow{2}{*}{ Mihrap } & 8 & Mihrap bilgisi (var/yok) \\
\hline & & 9 & Genel biçim \\
\hline \multirow{2}{*}{6} & \multirow{2}{*}{ Kafa } & 10 & Genel biçim \\
\hline & & 11 & Kalınlık \\
\hline 7 & Sap & 12 & Genel biçim \\
\hline
\end{tabular}

Turkish Studies, 16(5) 
Tablodan hareketle yedi farklı bölgeye ait on iki bilginin ortaya çıtığı söylenebilir. Kemençe çalgısında yapımcı bilgisine ulaşma amacıyla biçemsel özellikler açısından gözlemlenen temel bölgelerin varlığı ve bu bölgelerin 'hangi bölgeler' olduğu sorusunun cevap bulması, bu araştırma açısından önemlidir. Bununla birlikte görüşme kişileri tarafından araştırmaya konu olan çalgının üreticisi olarak görülen Baron yapımı kemençelerde, 'tutarlı' bir biçemsel özelliğin varlığından söz edilmesi, bu bilginin ötesine de geçildiğini göstermektedir. Söz konusu bölgelere ilişkin bu özelliklerin, adı geçen ustanın biçemsel özellikleri olarak kabul edilebilmesi, ustaya ait olduğu, kişi ve kaynaklarca ifade edilen çok sayıda örnek çalgı üzerinde yapılacak inceleme sonucu ortaya çıkarılacak bilginin derlenmesi sonucunda mümkün hale gelecektir. Bununla birlikte bu araştırmanın konusu dışnda tutulan, ustanın çalgılarında görülen süslemelerin özelliklerine ait bilgi de biçeme ilişkin tespiti destekleyecek önemli bir unsur olarak derlenmeli ve söz konusu amaç doğrultusunda ayrıca değerlendirilmelidir.

$\mathrm{Bu}$ araştırma ile birlikte daha önce birçok Avrupa çalgısı için kullanılarak etkinliği kanıtlanmış bir yöntem olan bilgisayarlı tomografik tarama teknolojisinin kullanımına ilişkin ilk deneme, müzik geleneğimizin önemli çalgılarından biri için gerçekleştirilmiştir. Ülkemizde bulunan tarihi öneme sahip diğer eski çalgıların da benzer şekilde incelenmesi ve bilgilerinin kayıt altına alınması, kapsamlı bir envanterin oluşmasına hizmet edecek ve ülkemizde çalg1 yapım 'geleneğinden' söz edilebilmesi için ihtiyaç duyulan 'tarihsel referansın' oluşumu için oldukça önemli bir katkı sağlayacaktır. Bununla birlikte söz konusu çalışmalar çalgılarn morfolojik özellikleriyle ilgili bilgi kadar, içinde oldukları kültürel ve estetik evren hakkında da bilgi sunacaktır. Bu çerçeveden bakıldığında geleneksel çalgılarımız, sadece biçimsel özellikleri ile bile 'doğrudan' ele alınmayı hakkedecek konumdadır. Benzeri araştırmaların artması ve nitelikli incelemelere ait sonuçların paylaşımı aracılığı ile kültürel farkındalık arttırılmış, Türkiye'de ilgili alana yönelen bireylerin yurtdışında aynı alanda faaliyet gösteren meslektaşları ile rekabet gücü yükselmiş ve çalgı yapım sanatı ile uğraşan, bu alanda araştırmaya ve kendini geliştirmeye ilgi duyan yeni kuşak, ihtiyaç duyduğu somut inceleme materyaline kavuşmuş olacaktır.

\section{Kaynakça}

Aksoy B. (1999). Osmanlı Musiki Geleneğinde Kadın. Osmanlı Kültür ve Sanat Ansiklopedisi, 788-800.

Aksoy, B. (2003). Avrupalı Gezginleri Gözüyle Osmanlılarda Musiki. Pan Yayıncılık.

Arel H. S. (1948). Kemençe Beşlemesi Hakkında Hatıralar ve Düşünceler. Musiki Mecmuası, 6, 38 .

Birsel, S. (1976). Ah Beyoğlu Vah Beyoğlu, Sel Yayıncılık.

Cavka, M., Petaros A., Kavur L., Skirln J., Minaric Missoni E., Jankovic I. \& Brkljacic B. (2013). The Use of Paleo Microbiological Testing in The Analysis of Antique Cultural Material: Multislice Computer Tomography, Mammography, and Microbial Analysis of the Trogir Cathedral Cope Hood Depicting St. Martin and a Beggar. Acta Med. History Adriatica, 11(1), 45-54.

Cemil, M. (1947). Tanburi Cemil'in Hayatı. Sakarya Basımevi.

Çolakoğlu, G. (2008). Anadolu'dan Balkanlara Armudi Biçimdeki Kemençeler: Tarih, Teknik ve Geleneksel İcrasına İliş̧kin Karşılaştırmalı Bir Analiz, [Yayımlanmamış doktora tezi] İstanbul Teknik Üniversitesi, Sosyal Bilimler Enstitüsü.

Falke, T. H., Zweypfenning-Snijders M.C., Zweypfenning R.C. (1987). Computed Tomography of An Ancient Egyptian Cat. Journal of Computed Assist Tomopraphy, 11(4), 745-747. 
https://doi.org/10.1097/00004728-198707000-00044.

Ergün, H. (2019). Yapraklı ve İğne Yapraklı Ağaçlarda Homojen Öz Işınların Morfolojik İşlemlerle Belirlenmesi. Mühendislik Bilimleri ve Tasarım Dergisi, 7 (1), 52-59.

Gattoni, F., C. Melgara, C. Sciola \& C. M. (1999). Unusual Application of Computerized Tomography: The Study of Musicl Instruments. Radiology, 97(3), 170-173.

Harwood, Nash DCF. (1979). Computed Tomography of Ancient Egyptian Mummies. Journal of Computed Assist Tomography, 3(6), 768-773.

Hoffman, H., Torres William E. \& Ernst Randy D. (2002). Paleoradiology: Advanced CT

in the Evaluation of Nine Egyptian Mummies. RadioGraphics, 22(2), 377-385. https://doi.org/10.1148/radiographics.22.2.g02mr13377.

Küçükebe, M. (2016). Multidsipliner Bir Yaklaşım: Bilgisayarlı Tomografik Tarama ve İlişkili İnceleme Tekniklerinin Çalgıbilim Çalışmalarında Kullanımı. Turkish Studies, 11(2), 895918. http://dx.doi.org/10.7827/TurkishStudies.9192

Marx, M, D’Auria SH. (1988). Three-Dimensional CT Reconstructions of Ancient Human Egyptian Mummy. American Journal of Roentgenology, 186(3), 55-61.

Mazansky, C. (1993). CT In the Study of Antiquities: Analysis of a Basket-Hilted Sword Relic from a 400-years-old Shipwreck. Radiology, 186(3), 55-61. http://dx.doi.org/10.1148/radiology.186.3.55a.

Notman, D., Tashijan J., Aufderheide A.C. (1986). Modern Imaging and Endoscopic Biopsy Techniques in Egyptian Mummies. American Journal of Roentgenology, 146, 93-96.

Orhon, C. (1985). "Tel Boyları Eşitlenmiş Dört Telli Klasik Kemençe”, İstanbul Teknik Üniversitesi Türk Musikisi Devlet Konservatuarı II. Türk Musikisi Sempozyumu, 3.

Sirr, S.A., Waddle J.R. (1989) Scroll of A Cello. Radiology, 173(2), 446.

https://doi.org/10.1148/radiology.173.2.446.

Sirr, S.A., Waddle J.R. (1997). CT Analysis of Bowed Stringed Instruments. Radiology, 203(3), 639-646. https://doi.org/10.1148/radiology.203.3.9169708

Sirr, S.A, Waddle J.R. (1999). Use of CT in Detection of Internal Damage and Repair and Determination of Authenticity in High-Quality Bowed Stringed Instruments", Radiography-ics, 19(3), 639-646. https://doi.org/10.1148/radiographics.19.3.g99ma09639

Sirr, S.A., Waddle J.R. (1999). Computed Tomography of Humans and Bowed Stringed Instruments. Some Interesting Similarities. Minn. Med., 82(10), 51-53.

Sirr, S.A., Waddle J.R. (2009). X-ray CT Measurements of the Internal Corpus Volume and a New Soundpost-Corpus Volume Relationship for Stringed Instruments of the Violin Family. Journal of Violin Society of America, 22(1), 1-12.

Sirr, S.A., Waddle J.R. (2014). Thin-Section X-Ray CT "Dissection" of Front and Back Plates, Fingerboards, and Corpus Volumes of 14 Cremonese Stringed Instruments: Density, Mass Distribution, and "Balanced Chi" Relationships. Journal of Violin Society of America, 24(2), 170-188.

Sirr, S.A. Waddle J.R., (2014a) Normal Age Related Distotional Changes of Bowed Stringed Instruments. Journal of Violin Society of America, 24(2), 189-196.

Sirr, S.A. (2014b). Climate Conundrum. The Strad, 61-63.

Ulu, M.O. (2008). Parçacık Dedektörlerinin Tıpta Kullanımı, [Yayımlanmamış Yüksek Lisans Tezi] Çukurova Üniveritesi Fenbilimleri Enstitüsü. 
Muhsin Kitap, İki Baron Kemençesinin Devr-i Alemi. (2021) Erişim adresi https://muhsinkitap.com/iki-baron-hikayesi 